Research Report No. 37/2008

\title{
Individual Emergencies and the Rule of Criminal Law
}

François Tanguay-Renaud

Osgoode Hall Law School of York University, FTanguay-Renaud@osgoode.yorku.ca

Follow this and additional works at: http:// digitalcommons.osgoode.yorku.ca/clpe

\section{Recommended Citation}

Tanguay-Renaud, François, "Individual Emergencies and the Rule of Criminal Law" (2008). Comparative Research in Law \& Political Economy. Research Paper No. 37/2008.

http://digitalcommons.osgoode.yorku.ca/clpe/207 


\section{TP Comparative Research in Law \& Political Economy}

\section{CLPE RESEARCH PAPER 37/ 2008}

\section{François Tanguay-Renaud} Individual Emergencies and the Rule of Criminal Law

EDTORS: Peer Zumbansen (Osgoode Hall Law School, Toronto, Director, Comparative Research in Law and Political Economy, York University), John W. Cioffi (University of California at Riverside), Lindsay Krauss (Osgoode Hall Law School, Toronto, Production Editor) 

CLPE Research Paper 37/2008

Vol. 04 No. 07 (2008)

\title{
François Tanguay-Renaud
}

\section{INDIVIDUAL EMERGENCIES AND THE RULE OF CRIMINAL LAW}

\begin{abstract}
This is the penultimate draft of a paper initially presented in the Oxford Jurisprudence Discussion Group and currently under review at Law and Philosophy. The paper assesses the relationship between individual emergencies and criminal law in light of the ideal of the rule of law and Joseph Raz's thesis about the normal justification of authority. After sketching out the main theoretical positions on how criminal law ought to provide for its own potential failure in the face of private emergencies, I argue that it is only in the most extreme and generalized cases that its sole legitimate response is to disclaim all competence in favour of its subjects. Whereas, in other cases (the focus of the paper), the criminal law may not be able to provide legitimate ex ante guidance, it may still be able to preserve the legitimacy of its authority. It may do so by granting some practical latitude to its subjects confronted with individual emergencies to act in accordance with morality, and by vindicating their correct responses ex post facto. The argument rests on the premise, which I defend, that morality never lapses even in the face of emergencies and that, therefore, the criminal law can always expect its subjects to abide by it. I then go on to contrast justification and excusatory defences as means of providing moral latitude to individuals facing emergencies, and conclude by refuting the assumption that people typically act irrationally when confronted with emergencies.
\end{abstract}

Keywords: Emergencies, individual emergencies, private emergencies, criminal law, justifications, excuses, permissions, legal powers, rule of law, authority, normal justification thesis, delegation, concept of morality, responsibility, rationality, risk, probability, reasons, Raz, Fletcher, Horder, Tadros, Thorburn, Wilson, Gardner.

JEL classification: K14 


\section{Author Contact:}

François Tanguay-Renaud

Osgoode Hall Law School, York University

4700 Keele St. Toronto Ontario, M3J 1P3

Email: FTanguay-Renaud@osgoode.yorku.ca 


\title{
INDIVIDUAL EMERGENCIES AND THE RULE OF CRIMINAL LAW
}

\author{
François Tanguay-Renaud *
}

\section{INDIVIDUAL EMERGENCIES AND CRIMINAL LAW: AN INTRODUCTION}

Human behaviour and the incidence of harm tend to be closely related, and societies often feel the need to regulate this nexus stringently. In the words of Stephen J. Morse:

Human beings are injurious and all too often lethal to themselves and others. Surely more people have been killed and injured by the acts of others and themselves than by natural disasters. Only toxic microbes are as dangerous as people. All civil societies, including the least developed, therefore create numerous public and private socializing institutions and practices to cabin the injurious propensities of their members. ${ }^{1}$

Criminal law is one of these institutions of social control. It is often hailed as "the primary instrumentality for preventing people from intentionally or

*Assistant Professor, Osgoode Hall Law School, York University. This paper is under review at Law and Philosophy. I wish to thank John Gardner, Claire Grant, Stephen Shute, and Dori Kimel, and the participants in the Oxford Jurisprudence Discussion Group where an earlier version was presented in the Fall of 2005.

${ }^{1}$ Stephen J. Morse, 'Neither Desert nor Disease', Legal Theory 5 (1999): 265-309 at p. 267. 
recklessly harming one another."2 In many societies, the institution's ambitions are even wider, and criminal law seeks to prevent behaviour that negligently, sometimes even accidentally or 'strictly,' causes harm. ${ }^{3}$ However, Morse reminds us, restraining practices and techniques such as criminal law "are never foolproof: All fail sometimes, often disastrously."

When criminal law fails to prevent armed attacks, rape attempts, kidnappings, arsons or violent burglaries, the resulting situation is often one of emergency for those facing the predicament. In such situations, often unforeseen, individuals typically face great risks of harm and need to react urgently if harm is to be averted or minimised. More often than not, the law is in no position to provide any (further) assistance. The situation may be too extraordinary for the law to assess its specificities accurately and provide helpful guidance ex ante facto. If it is in a position to provide such guidance, the law may then be unable to convey it in time and effectively enough to those who need it. Natural emergencies may constrain the law in similar ways. Consider the example of the hiker who, caught in a storm, must break into a cabin if she is to save her life. As Nasser Hussain remarks, "If the ethereal images of distance, mediation, and universality are embedded in the expression rule of law, they are entirely opposite of the images associated with emergency: direct force, singular cases, final judgments, and so on." 4 Such examples and images pave the way to the general puzzle I want to address in this article. If the rule of (criminal) law is to be contrasted with the rule of people by themselves, ${ }^{5}$ that is to say, with anarchy, to what extent is it an achievable and desirable ideal given the inescapable reality of emergencies?

2 Joel Feinberg, The Moral Limits of the Criminal Law Volume 1: Harm to Others (Oxford: Oxford University Press 1987), p.31.

${ }^{3}$ On the issues of criminal negligence and strict liability in English law: A.P. Simester and G.R. Sullivan, Criminal Law: Theory and Doctrine $\left(2^{\text {nd }}\right.$ edn, Oxford: Hart Publishing, 2003), pp. 149-156, 167-191. To this list should perhaps be added attempts at causing harm that fail, incitements, as well as conspiracies to cause harm.

${ }^{4}$ Nasser Hussain, The Jurisprudence of Emergency: Colonialism and the Rule of Law (Ann Arbor: University of Michigan Press, 2003), p. 16.

${ }^{5}$ F.A. Hayek, The Constitution of Liberty (London: Routledge and Kegan Paul, 1960), p. 165 traces this impersonal formulation of the ideal of the rule of law-understood in 
To be more precise, criminal law, because it seeks to regulate human behaviour by affecting the circumstances of human actions, has to grapple with reasons for action that may compete with it, such as emergencies. Some theorists have sought to explain law's position-and $a$ fortiori criminal law's position-in relation to competing reasons by remarking that law claims for itself absolute and legitimate authority to regulate all forms of human behaviour or, in other words, purports to exclude from human consideration all reasons that conflict with it. In Joseph Raz's useful terminology, law claims to be a system of 'protected reasons': reasons to act or refrain from acting in certain ways, which concurrently serve as second-order reasons - exclusionary reasons - not to act for conflicting reasons. ${ }^{6}$ Now, to genuinely claim or purport entails that one strives to realise what one claims or purports. The law, by virtue of its claim to have authority to regulate all forms of human conduct, ought to endeavour to ensure that those to whom its guidance is directed can find out what it is and act accordingly. There exists a relative consensus (which I do not intend to challenge here) on how it can, formally and generally speaking, best strive to achieve this: laws should be clear, consistent, open, prospective, general and stable; legislative and executive action should be governed by laws with those characteristics; and there should be accessible courts which have review powers over the implementation of the aforementioned principles. ${ }^{7}$ But that the law needs to be capable of guiding the behaviour of its subjects does not necessarily mean that it can, or should, aim to do so absolutely - that is to say, in all

opposition to the 'rule of man' (which I formulate gender-neutrally as the 'rule of people')—back to Aristotle Politics 1287a.

6 Joseph Raz, Practical Reason and Norms ( $2^{\text {nd }}$ edn, Oxford: Oxford University Press, 1990), pp. 141-146, 150-151; Joseph Raz, The Authority of Law (Oxford: Oxford University Press, 1979), pp. 17-19.

7 These are the formal requirements, or desiderata, of the 'rule of law' as recognized by a variety of authors. See, e.g., Lon Fuller, The Morality of Law ( $2^{\text {nd }}$ edn, New Haven: Yale University Press, 1969), ch. 2; Raz (1979, pp. 214-219); John Finnis, Natural Law and Natural Rights (Oxford: Clarendon Press, 1980), pp. 270-271. I label these requirements 'formal,' by opposition to more substantive criteria, such as the protection of particular rights, also advocated by some theorists under the heading of the rule of law. 
instances - or at least that it can and should always seek to guide human behaviour according to all the desiderata outlined above. At the risk of stating the obvious, criminal law should seek to provide guidance that is legitimate, in the sense of being morally justified. In this article, I want to explore to what extent it can do so in situations of individual (as opposed to more generalised and disordering) emergencies, which people confront in their 'non-official' (some might say 'private') capacities.

First, I survey the main conflicting theoretical positions on how criminal law ought to contemplate and provide for its own potential failure in the face of individual emergencies. I argue that when the de facto authority of the state is generally not in question, the criminal law's answers to such failures must not take the form of full ex ante disclaimers of competence. Rather, the criminal law may seek to engage its subjects while remaining acutely aware of the limits imposed on its authority and guidance ability by the exigencies of the situation. Of course, generalised emergencies may sometimes subvert the authority of law in more extensive ways and call for more drastic disclaimers of competence, but they do not constitute my focus here. In a final parenthesis, I seek to make the case that whenever the rule of people is contrasted with the rule of law in the context of emergencies, it is the rule of rational people responsible for their choices and actions that is first and foremost at issue. This realisation, I contend, should have some important bearing on the criminal law's treatment of individuals in emergency predicaments.

\section{Solving The Puzzle: How CRIMinal LAW OUGHT TO CONTEND WITH INDIVIDUAL EMERGENCIES}

\section{A. THE THEORETICAL CAMPS}

Scholars have recently produced an appreciable body of criminal law theory literature discussing the role of individual emergencies in the fabric of Anglo-American criminal law. Whereas these writings never systematically define nor explain the notion, most theorists agree that 
urgency-induced necessity is a central dimension of the concept. Human beings qua rational creatures unavoidably encounter a wide range of rational pressures in the course of their life. One way of differentiating such pressures is to systematize them on a linear axis with urgency as the variable, keeping all else (such as the seriousness of the consequences that might result if the emergency is not appropriately addressed) constant. While some pressing situations necessitate an immediate reaction, time is less of the essence in others. The difference is often one of degree, but can also be cast in stark terms for the sake of clarity of exposition. Contrast the following two examples: (1) A pedestrian is violently attacked by a mugger who attempts to kill her. She finds herself constrained to counterattack in self-defence, and kills her assailant in the process. (2) A caring father concerned with alleviating the constant and severe pain experienced by his twelve-year-old daughter who, in addition to being quadriplegic, suffers from a severe and degenerating form of cerebral palsy and has the mental capacity and autonomy of a four-month old baby, kills her out of mercy. ${ }^{8}$ Both the pedestrian and the father face predicaments which, in ordinary language, could be described as 'pressing.' However, one significant difference between them is that the pedestrian's opportunities to avoid serious harm are highly time-constrained. She has virtually no time to deliberate her reaction, she may have no time to call for help or flee, and so on. On the other hand, the father has more latitude when considering action. In both daily conversation and theoretical discourse, the distinction is often underlined by referring to situations of the first kind, and not of the second, as 'emergencies.'

Many theorists recognise that emergency situations may have important ramifications for norms in general-they often focus, as will I, on prescriptive rules-and, more particularly, for the law. Others dispute this claim, and identify with the "acoustic separation" school of criminal law theory. According to this school of thought, the law ought, in an emergency, to give ex ante guidance on when ordinary citizens may, for example, justifiably kill or harm others, or steal or destroy somebody

\footnotetext{
8 Those were roughly the facts of the high profile Canadian case R. v. Latimer [2001] 1 S.C.R. 3 (Supreme Court of Canada). Note that in this case, the court explicitly refuses to characterize the predicament as a 'necessity' or an 'emergency.'
} 
else's property. ${ }^{9}$ Like in any other (non-emergency) case, it is then for judge or jury to decide whether that legal guidance was followed. One of the major weaknesses of this school of thought is that it tends to ignore the pressures exercised on the criminal law's guidance ability in emergency situations. Because he is not confronted with an emergency, the father in the previous example could, at minimal cost to his daughter, seek the guidance and assistance of the law and request a court order. ${ }^{10}$ Expecting the same kind of behaviour from the person unjustifiably attacked on the street would no doubt seem both unreasonable and impractical. She has virtually no time to deliberate her reaction, let alone an opportunity to resort to official guidance, if she wants to avoid or minimize the harmful consequences of the assault.

One might retort that although the criminal law can only be of little assistance at the time of the emergency, its ex ante directives may prepare, or 'socialise,' individuals by making it persistently clear how they must behave when such situations arise. The problem with this line of argument is that it fails to acknowledge that criminal law guidance is typically "an approximation, by rule, of a principled understanding of wrongful conduct. It states the normal case of wrongdoing, but fails to account accurately for wrongdoing in the extraordinary cases that arise under conflict and under the pressure of circumstances." ${ }^{11}$ For example, whereas taking somebody else's property without her consent may be, all

\footnotetext{
${ }^{9}$ To be sure, according to the main adherents of this theoretical current, justificatory criminal defences are 'rules of conduct' for the law's subjects. On the other hand, excuses are ‘rules of adjudication' directed at judges and juries. E.g. Meir Dan-Cohen, 'Decision Rules and Conduct Rules: On Acoustic Separation in Criminal Law', Harvard Law Review 97 (1984): 625-677 at pp. 637-639; P.H. Robinson, 'Rules of Conduct and Principles of Adjudication', University of Chicago Law Review 57 (1990): 729-771 at pp. 740-742.

${ }^{10}$ In many jurisdictions, if he judges that the suffering of his daughter is such that action should not be unduly delayed, he could further request that the court proceedings be fasttracked. Compare: Re A (Conjoined Twins) [2000] 4 All E.R. 961 (English Court of Appeal).

${ }^{11}$ G.P. Fletcher, 'The Nature of Justification' in Stephen Shute, John Gardner and Jeremy Horder (eds.) Action and Value in the Criminal Law (Oxford: Clarendon Press, 1993), pp. 175-186 at p. 177.
} 
things considered, wrong in the normal course of events, this may not be the case in emergency circumstances where other typically available opportunities for harm avoidance are absent. If legal rules are understood as entrenched generalisations of what behaviour is justified, they will inevitably be under-inclusive and over-inclusive from time to time (in relation to their underlying justifications). ${ }^{12}$ Thus, general criminal law guidance may be quite an ineffective and inappropriate way of regulating individual emergencies.

Similar realisations have led a number of theorists to argue that criminal law ought to deal differently with (at least some) emergencies. It ought to be less (or differently) demanding of the individual, and make extra space for him or her to assess how to act. This is the assumption on which I intend to proceed. However, even amongst the theorists who share my assumption, views diverge as to how and to what extent the criminal law ought to create such extra space.

One view asserts that, in individual emergency situations, the criminal law ought to disclaim competence in favour of the agent in the predicament. Such an institutional view is perhaps best articulated by George Fletcher who, assimilating "actual situations of necessity" to "emergencies," argues that:

[In necessity cases], the imminence requirement expresses the limits of governmental competence: when the danger to a protected interest is imminent and unavoidable, the legislature can no longer make reliable judgments about which of the conflicting interests should prevail. Similarly, when an attack against individuals is imminent, the police are no longer in a position to intervene and exercise the state's function of securing public safety. The individual right of self-defence kicks in precisely

${ }^{12}$ See generally Frederick Schauer, Playing by the Rules: A Philosophical Examination of Rule-Based Decision-Making in Law and in Life (Oxford: Clarendon Press, 1991), ch 23. 
because immediate action is necessary. Individuals do not cede a total monopoly of force to the state. ${ }^{13}$

According to Fletcher, because the government is generally incompetent to decide in advance who shall bear the costs in a situation where the time frame is extremely short, the harm potential high, and particulars often unpredictable, it must acknowledge its limitations and allow individuals to make that decision for themselves. As per the age-old saying, necessity, and a fortiori emergency, knows no law. It is the individual who, within the parameters prescribed by the situation of immediate risk, is (more) competent to make the decision in question. The law ought to recognize this fact and move out of the way.

Disclaimers of competence in favour of individuals are not unheard of in the criminal law context. Take the case of outlawry in those societies which recognise, or used to recognise, such an absence of status. In English medieval times, to take a concrete example, an outlaw was one who, because of his bad acts, had been banished from society and placed outside the protection of the law. By declaring someone an outlaw, the state was acknowledging its inability to punish someone who had violated its laws, and was thereby disclaiming its competence to punish him in favour of any of his or her victims, the victims' families, a posse or, for that matter, anyone who might want to join in. ${ }^{14}$ An outlaw was fair game, which explains the maxim: "Let them be answerable to all, and none to them." Fletcher's (in)competence argument seems to run along similar lines. The question of emergency does not solely affect the criminal law's ability to make the judgment in question reliably and guide individual behaviour appropriately; it also limits its capacity to police its judgment, at least ex ante facto, if it decides to formulate one nonetheless. ${ }^{15}$ Therefore,

${ }^{13}$ G.P. Fletcher, 'Domination in the Theory of Justification and Excuse', University of Pittsburg Law Review 57 (1996): 553-578 at pp. 569-570.

${ }^{14}$ Outlawry does not exist anymore in England, as reiterated in Cross v. Kirby The Times 5 April 2000.

${ }^{15}$ Benjamin C. Zipursky, 'Self-Defense, Domination, and the Social Contract', University of Pittsburg Law Review 57 (1996): 579-614 at pp. 585-586, argues that Fletcher's argument does not solely rest on competence, but also on a conception of the social 
it is the individual, and not the law, who ought to have the authority to make decisions within the parameters of an emergency situation and, to that extent, the rule of law should give way to the rule of people by themselves.

One might here agree with Fletcher that the criminal law is by and large incompetent in situations of emergency, but argue that its incompetence does not come-or does not solely come-from its inability to make the appropriate decision or to police it ex ante. Instead, one might contend, the law's incompetence in situations of emergency stems from its inability to convey effectively its decision to the individual in the predicament. Although this nuance is interesting, both positions are really two sides of the same coin: whether the law is incompetent to decide and police, or incompetent to make its guidance heard, it is incompetent. This affirmation is consistent with Fletcher's contentions that the core of the individual emergency problématique rests with "the proper allocation of authority between the state and the citizen," and that this issue "falls into the domain of political rather than moral theory."16 For the sake of clarity, I shall refer to this view as the 'institutional view.'

Another view is that, although it ought to show some flexibility, the law need not surrender its rule in the face of individual emergencies. In many such cases, the law remains competent to engage the individual, but might need to do it differently than it usually does. This is the position espoused by theorists like Jeremy Horder, who writes that: "It is not reasonable to expect citizens to do more, in such extreme and exceptional situations, than follow the guidance of morality, in the expectation that they will, ex post facto, be vindicated at law." ${ }^{\prime 7}$ As I stressed earlier, the law generally purports to exclude from its subjects' contemplation all

contract. Even if Zipursky is right and Fletcher did not draw the distinction clearly enough, I believe that the two arguments can and should be distinguished. In this paper, I proceed on the basis of the competence argument alone.

${ }^{16}$ Fletcher (1996, p. 570).

${ }^{17}$ Jeremy Horder, 'Killing the Passive Abuser: A Theoretical Defence' in Stephen Shute and A.P. Simester (eds.) Criminal Law Theory: Doctrines of the General Part (Oxford: Oxford University Press, 2002), pp. 283-298 at p. 286. 
reasons for action which conflict with it, and to replace them with its own guidance. However, as I also suggested, in cases of individual emergencies, the criminal law is unlikely to be able to replace other considerations consistently and reliably. Theorists like Horder argue that one alternative open to the law in such situations is to allow its subjects to rely directly on morality. Whereas non-legal social conventions may, like the law, become unreliable sources of guidance in times of emergency, ${ }^{18}$ it is almost a truism that one always ought to act morally, even in the face of an emergency. Although an anarchist attitude vis-à-vis the law and social conventions is-irrespective of its rightness or wrongness-intelligible, amoralism is not. Morality is binding on us ultimately, irrespective of what we feel about it and of the predicament in which we find ourselves. Of course, different moral considerations than those that are otherwise applicable may sometimes prevail in emergency situations, but morality itself does not cease to apply or go awry, despite arguments to the contrary by a number of theorists. I shall bracket this point for the moment, and return to it in more detail in the next section.

What I seek to emphasise at this stage is that, by permitting direct reliance on morality within defined parameters, the law may aspire to engage more optimally with those facing emergencies. In the pressure of the moment, it does not leave them to behave according to their whims, but invites them to exercise moral judgment. In the process, it avoids distorting the complex rational conflicts that they might be forced to confront, while retaining the authority to review their conduct ex post facto and hold them accountable for unreasonable mistakes and excesses. For ease of exposition, I shall refer to this view as the 'moral view.' As Horder remarks, the law may, and sometimes will, choose to refrain from inviting individual moral assessments in emergencies with larger moral and political implications than can possibly be accounted for by a person acting alone. ${ }^{19}$ However, as I will discuss further in section B3(c), such a

${ }^{18}$ This is not to say that in situations where the law is hopelessly unreliable, social conventions may never be of assistance. However, because emergencies are situations which typically throw uncertainty into our social norms, their reliability is, mutatis mutandis, as open to question as the law's competence.

19 Jeremy Horder, 'On the Irrelevance of Motive in Criminal Law' in Jeremy Horder (ed.) Oxford Essays in Jurisprudence Fourth Series (Oxford: Oxford University Press, 2000), pp. $173-192$ at pp. 177-184, 187-188. 
decision will always be at risk of being tagged as harsh, illegitimate or immoral, and even of being generally disobeyed by morally-abiding individuals, when it is indeed too inflexible.

From a rule of law perspective, an apparent advantage of the moral view is that it seems to stand up for the law's authority in situations in which the institutional view would mandate total surrender to the individual. Who is right? The simple answer is that both of these views have some truth to them. In fact, the divide between them is rather artificial. In the next section, I will argue that the two approaches should be understood as converging or, better, as emanating from a single concern. Depending on the context and scope of the emergencies to which law and individuals are confronted, one of the previous models will sometimes seem more appropriate than the other. However, the choice, if there is one to be made, will generally be best articulated in terms of the legitimacy of the law's authority.

\section{B. LEGAL AUTHORITY AND INDIVIDUALS’ MORAL UnIVERSE}

\section{PRELIMINARY REMARKS 1: REASONS, LEGAL AUTHORITY AND JOSEPH RAZ'S INSIGHTS}

To be able to identify which model accurately reflects how criminal law ought to contend with emergencies, one must keep in mind the various ways in which reasons for action may be defeated, thus making them improper justificatory grounds for action. Reasons may override conflicting reasons because, on the 'balance of reasons,' they are comparatively weightier. Irrespective of their weight, some reasons may also exclude, and thus defeat, some or all competing reasons from one's consideration. ${ }^{20}$ Finally, reasons can be cancelled by circumstances which cause them to stop being grounds for action. Such cancelling circumstances are not conflicting reasons: they are facts which make it the

${ }^{20}$ On the difference between exclusionary and ordinary (or pro tanto) reasons, see Raz (1990, pp. 25-28, 35-48, and Postscript). Of course, exclusionary reasons may sometimes be overridden in what Raz calls 'second-order' conflicts (47). 
case that the result of the action for which there was a reason is no longer rationally salient, say, because it is no longer achievable-e.g. the person needing help has died. The relevance of these preliminary distinctions will become clearer as the argument unfolds.

Another point is worth reaffirming at this preliminary stage. As I already suggested, legal systems seek to position themselves, or mediate, between the reasons that apply to their subjects and the subjects themselves, by providing guidance via protected reasons for action-i.e. reasons for action which concurrently exclude conflicting reasons-in the form of duties, rules, and so forth. In Joseph Raz's terminology, every legal system claims for itself, at least in principle, all-encompassing authority to mediate between people and reasons for action that it does not itself provide. Such a claim, adds Raz, is by its very nature a claim to possess legitimate authority. ${ }^{21}$ The question that must then be asked is when the law's claim is, all things considered, legitimate. In other words, when are the law's subjects justified in following its guidance, and when is the law justified in issuing directives to guide their behaviour?

A first consequence of Raz's characterization of (practical) authority is that, to be legitimate, the law must be in a position to make a practical difference to the behaviour of its subjects by, for instance, extricating them from coordination problems and Prisoner's Dilemma type situations. For this to be so, the law must have a significant degree of de facto authority over people, in the sense of actual power over them and obedience by them. Otherwise, it does not have what it takes to act as a practical authority, let alone a legitimate one. ${ }^{22}$ However, Raz's main

${ }^{21}$ Joseph Raz, 'Authority, Law, and Morality’ in Ethics in the Public Domain (Revised edn, Oxford: Oxford University Press, 1994), pp. 210-237 at p. $215 \mathrm{ff}$.

${ }^{22}$ See Joseph Raz, The Morality of Freedom (Oxford: Oxford University Press, 1986), p. 76; Joseph Raz 'Facing Up: A Reply', Southern California Law Review 62 (1989): 11531235 at p. 1194. H.L.A. Hart makes a similar point in The Concept of Law (2nd edn, Oxford: Clarendon Press, 1994), p. 103-104. Note, however, that Raz also recognises the existence of some marginal cases of legitimate practical authority without de facto authority, thus underlining an important distinction between authority with the power to use it effectively and someone who is entitled to have authority but does not have it. Joseph Raz, 'The Problem of Authority: Revisiting the Service Conception', Minnesota Law Review 90 (2006): 1003-1044 at p. 1005. 
point is deeper. The law's authority is legitimate (qua justified) when its subjects are more likely to comply with the reasons that ought to govern their behaviour by following the law's directives than by trying to follow those reasons directly. This might be the case when the law has greater expertise or superior knowledge, a distinctive capacity to solve coordination problems or to strengthen our resolve to act as we ought to, or simply because it has better moral judgment. This is Raz's "normal justification thesis," on which I intend to rely. ${ }^{23}$

While controversial, Raz's account of the normal justification of authority has been widely influential, and rightfully so. It is precise, powerful, and a great advance over previous efforts. Theorists do not hesitate to celebrate it as part of "the best recent work on authority." 24 More specifically for my purposes, the normal justification thesis sheds light on the fact that, although law is sometimes praised for its symbolic or expressive value, its role is first and foremost instrumental. Law qua practical authority needs to serve its subjects: it needs to guide them in ways that are likely to make things better for them. If it is not to become dead letter, it must seek to help them decide better which actions are right for them than if they acted solely according to their own lights. As Raz argues, the justification of law's authoritative guidance in any given case (normally) depends on how well it performs in this regard. Thus, the normal justification thesis provides us with a framework for understanding the instrumental limits of law. When the law is ill-placed to make things better for its subjects, it may be unjustified in seeking to do so, at least in its usual authoritative fashion. Individual emergencies are a case in point. As I suggested earlier, the law may be particularly ill-placed to seek to assist its subjects in its usual way in emergency circumstances, due to its inability to move fast and effectively enough. The normal justification thesis provides us with a platform from which to understand how law, and a fortiori criminal law, ought to provide for this type of predicament.

${ }^{23}$ For an early formulation and defence of the thesis, see Raz (1986, p. 53). In his Raz (2006), he presents further helpful refinements of his views and a reply to many critics.

24 Jeremy Waldron, ‘Authority for Officials' in Lukas H. Meyer, Stanley L. Paulson and Thomas W. Pogge (eds.) Rights, Culture, and the Law: Themes from the Legal and Political Philosophy of Joseph Raz (Oxford: Oxford University Press, 2003), pp. 45-69 at p.45. 
As another preliminary matter, I also want to address the view (which I left unarticulated and undefended in the last section) that morality as a guide to action does not cease to be reliable and to apply in the face of emergencies. Although this claim might seem obvious to some, it is not to others, and underlies an important discomfort surrounding the concept of morality. A parenthesis seems necessary at this point to clarify the implications of my affirmation for the discussion that follows.

\section{(i) The challenge}

"Erst kommt das Fressen, dann kommt die Moral" ("Grub first, then morality"), wrote playwright Bertolt Brecht at the end of the second act of The Threepenny Opera. In other words, one might argue, when the avoidance of serious harm is at stake, perhaps paradigmatically in cases of emergencies threatening one's preservation, moral considerations take a back seat or are altogether suspended. This view has had many philosophical incarnations over the centuries. For example, in a famous passage in Chapter 15 of Leviathan, Thomas Hobbes argues that when adherence to the "laws of nature" would be disastrous, then "all bets are off":

The laws of nature oblige in foro interno; that is to say, they bind to a desire they should take place: but in foro externo; that is, to the putting them in act not always. For he that should be modest, and tractable, and perform all he promises, in such time, and place, where no man else should do so, should but make himself a prey to others, and procure his own certain ruin, contrary to the ground of all laws of nature, which tend to nature's preservation. ${ }^{25}$

${ }^{25}$ As Hobbes goes on to specify, 'the science [of the laws of nature], is the true and only moral philosophy.' Thomas Hobbes, Leviathan (Oxford: Oxford University Press, 1996), p. 105. 
It is noteworthy that some people dispute interpretations of Hobbes's work according to which he believed that moral considerations could be suspended altogether. They argue instead that Hobbes thought that morality could sometimes become all permissive in foro externo for the sake of self-preservation, without ever lapsing. They cite as evidence his first and fundamental law of nature "that every man, ought to endeavour peace, as far as he has hope of obtaining it; and when he cannot obtain it, that he may seek, and use, all helps, and advantages of war." ${ }^{26}$ No doubt, the line between the view that morality can become all permissive in the face of severe emergencies and the view that moral considerations may be altogether suspended is quite thin. Yet, some contemporary theorists seek to avoid any such source of confusion and endorse the latter claim in no equivocal terms. James Griffin, for example, writes that "Not even morality, to my mind, applies universally to moral agents regardless of conditions: for example, it does not apply if conditions get desperate enough-sauve-qui-peut situations." ${ }^{27}$ Views like these point to a deep question about the status of morality when its constraints are severely disadvantageous. Are they sound?

My argumentative strategy will be twofold and more or less indirect. First, I will argue that whereas some conceptions of morality make the view that morality may lapse or go awry intelligible, others do not. I will then seek to spell out my reasons for defending the latter in the context of this article, thus clarifying my claim that morality applies consistently, both inside and outside emergency predicaments.

(ii) Jurisdictional and non-jurisdictional conceptions of morality

\footnotetext{
${ }^{26}$ Hobbes (1996, p. 87).

27 James Griffin, 'First Steps in an Account of Human Rights', European Journal of Philosophy 9 (2001): 306-327 at p. 325 (fn 19) [Emphasis added]. See also David Gauthier, Morals by Agreement (Oxford: Oxford University Press, 1986) for an interpretation of Hobbes's work that is overtly sympathetic to the view that morality can cease to be applicable.
} 
Bernard Gert writes that "although, not widely discussed, the definition of morality has great significance for moral theory." ${ }^{28}$ Cast in general terms, Gert's claim is intended to stimulate reflection about various dimensions of moral theorising and its subject-matter. However, to the extent that definitions are concerned with boundaries, his claim seems especially relevant to the debate over the scope of morality's applicability, with which I am concerned here. Is morality something that can cease to apply to us, lapse, or go awry?

Some theorists conceive of morality's reach as limited. For example, Bernard Williams refers to it as a "peculiar institution," a "special system, that demands a sharp boundary for itself." ${ }^{29}$ Others, like Terry Nardin, speak of the possibility of "an extra-moral world in which human beings are related to one another in the same way they are related to non-human things. ${ }^{30}$ Such representations allow theorists to speak of morality in terms of its jurisdiction, bounds, and branches-GEM Anscombe, for example, speaks of "law conception[s] of ethics." 31 For these theorists, morality may intelligibly fall short. It may compete and lose out in jurisdictional conflicts with normative systems that are at variance with it, be they legal, religious, or conventional. It may intelligibly 'fail to apply' or 'run out' in the face of non-moral (or extramoral) considerations. Morality, Williams tells us, is not the be-all and end-all of normativity or rationality (despite what it may claim). It may make mistakes and be criticised, defied, even ridiculed for it. It may omit important nuances, it may be overly unclear, it may be too demanding and

\footnotetext{
${ }^{28}$ Bernard Gert, 'The Definition of Morality' in E.N. Zalta (ed.) The Stanford Encyclopedia of Philosophy (Fall 2005 edn), online: $<$ http://plato.stanford.edu/archives/fall2005/entries/morality-definition/>.

${ }^{29}$ Bernard Williams, Ethics and the Limits of Philosophy (London: Routledge, 2006), pp. 7, 174.

${ }^{30}$ Terry Nardin, 'Emergency Logic: Prudence, Morality and The Rule of Law' in Victor V Ramraj (ed.) Emergencies and the Limits of Legality (Cambridge: Cambridge University Press, 2008), pp. 97-117 at p. 97.

${ }^{31}$ G.E.M. Anscombe 'Modern Moral Philosophy', Philosophy 33 (1958): 1-19 at p. 5.
} 
occupy fields from which it should keep away. In fact, Williams goes on to assert, we may be altogether "better off without it."32

Griffin's position, perhaps less radical, can be understood in a similar light. For him, morality is ill-suited to guide us in emergency situations where our survival is imminently and desperately at stake. "It is," he writes, "perfectly reasonable to go on saying that moral principles apply universally, that is, to us all simply in virtue of our being moral agents (that is, given that morality applies at all)." ${ }^{33}$ Whereas we may be unable to do away with morality within its proper sphere of jurisdiction, we ought to recognise that this sphere is not absolute and that morality is sometimes outright inapplicable, most notably in sauve-qui-peut situations. $^{34}$ Echoes of Brecht and Hobbes's positions permeate these remarks. Whereas, according to Hobbes, morality-i.e. the aggregate normative system of all "laws of nature"-always obliges in foro interno, it may not be a complete and unfaltering guide to action. Like Brecht seems to imply in his play, morality's jurisdiction as a guide to action is fundamentally limited by considerations of self-preservation. Thus, in

${ }^{32}$ Williams (2006, pp. 174, 180, 196).

${ }^{33}$ Griffin (2001, p.325, fn 19) [Emphasis added].

${ }^{34}$ In his earlier work, Griffin seems to acknowledge that the issue of jurisdiction is not as clear-cut as my account might make it seem. He writes that 'when it comes to the terribly hard choice between morality and survival,' prudential reasons may 'run, without boundary, into moral ones.' A bit later, he adds that:

[I]f acting justly might make the heavens fall, if that is the sort of requirement that justice turns out to be, then our collective self-interest might well outweigh it. If respecting rights could cause or fail to prevent catastrophe, then again selfinterest probably outweighs it. Whether these would be cases of pure selfinterest's outweighing morality or self-interest's taking on moral weight would also depend upon the content of moral reasons [...] we have to lay out moral reasons and see what place they occupy in the hierarchy.

James Griffin, Well-Being: It Meaning, Measurement, and Moral Importance (Oxford: Oxford University Press, 1986), pp. 160-162. There may be some truth to these remarks. However, I shall not seek to elucidate them more than by saying that they might be taken to point to the second, non-jurisdictional understanding of morality which I introduce below. 
reaction to Tom Sorell's observation that "much of everyday bourgeois morality could seem pointless if the emergency were imminent enough, enveloping enough, and final enough," potentially giving rise to "moral black holes," 35 these theorists would likely have a common reply. In such situations, they would say, morality is simply the wrong guide to action. People ought to ensure their own survival (or preservation) before seeking to act morally towards others.

Some theorists espouse a drastically different picture of morality. According to them, there are no moments in human history from which morality is absent. "The human world," writes Michael Walzer, "is a world of limitation, and moral limits are never suspended-the way we might, for example, suspend habeas corpus in a time of civil war." ${ }^{36}$ On this view, morality has no doctrine of jurisdiction setting out the conditions of its applicability. As Joseph Raz explains, "Talking of morality is just a way of talking of some of the reasons that people have. They apply to whomever they address. [...] Their scope of application is determined by their content."37

In this sense, morality refers to true-or valid-reasons. It should not be confused with anybody's beliefs about it. It applies to all agents capable of understanding it and binds them come what may, irrespective of their interest in it. Morality in this sense is sometimes described as the art of life. It cannot be criticised, defied, or ridiculed for omitting important nuances, for being overly unclear, for failing to provide adequate notice, or for being too demanding or overreaching. It adapts itself perfectly to all imperfect situations with which it deals, be they ordinary or exceptional in nature. For example, when an individual faces an emergency, the urgency of the situation typically restricts the opportunities for avoiding serious harm which are available to her. As a result, she may have undefeated reasons to act in certain ways which

\footnotetext{
${ }^{35}$ Tom Sorell, 'Morality and Emergency', Proceedings of the Aristotelian Society 103 (2002): 21-37 at p. 26.

${ }^{36}$ Michael Walzer, Arguing About War (New Haven: Yale University Press, 2004), p. 34.

${ }^{37}$ Joseph Raz, 'Incorporation by Law', Legal Theory 10 (2004): 1-17 at pp. 2-3.
} 
would not otherwise exist. To account for such predicaments, morality adapts its requirements and makes justifications and excuses available in circumstances where they would not otherwise be. ${ }^{38}$ Hence, one is sometimes morally justified or excused in resorting to force in selfdefence or in burning part of a neighbour's field to contain an expanding forest fire. Of course, a given moral reason may be defeated-overridden or excluded-by other reasons. Morality, as I have just said, is not inflexible. But morality as a whole cannot be ousted. For these nonjurisdictional theorists, an argument to the effect that it can would be unintelligible.

Such theorists would likely make a very different diagnosis of Tom Sorell's observation that 'bourgeois morality' sometimes seems pointless in extreme situations of emergency. They might concede that from the point of view of individual psychology, morality's hold on us may appear to lessen or lapse in the face of an emergency. Depending on the extent to which our rational capacity is impaired by events, such a perception may be excusable, or even, in some radical cases, evidence of our unfitness to be judged morally responsible for actions perpetrated under its influence. However, such a concession does not amount to an admission that morality sometimes does not apply. It is simply a recognition that pathology sometimes alters our perception of reality. Morality, these theorists would insist, has no jurisdictional limits. It never withers away or retreats in ways that create "moral black holes." Of course, they might add, there may be situations where 'bourgeois morality' seems pointless even to the fully rational agent. However, this is only because 'bourgeois morality' is a misrepresentation of morality, and often clings on to the sclerotic illusion of moral inflexibility-for example, to the idea that stealing is always unjustifiable, even in the face of an emergency. Consider the case of the unemployed poor. When such people have adequate alternatives to stealing - they receive sufficient charity, they are supported by adequate social security systems, and so forth-the conflict

${ }^{38}$ On defeated and undefeated reasons for action, justifications and excuses, see John Gardner, 'Justifications and Reasons' in A.P. Simester and A.T.H. Smith (eds.) Harm and Culpability (Oxford: Oxford University Press, 1996). Roughly speaking, if an action is justified the reasons for it are not defeated by those against it. The undefeated reasons for a justified action are those that justify it. On the other hand, excuses are for unjustified actions and are grounded in undefeated reasons for belief, emotion, and so on. 
between survival and reasons to respect the property of others may only be partial. On the other hand, when no such alternatives are available to them and their survival is imminently at stake, the conflict may become complete and its resolution in one sense or the other inescapable. In such situations, stealing may turn out to be an undefeated course of action. Food may then come first, yet, pace Brecht, come first in a morally acceptable way.

(iii) Why adopt a non-jurisdictional account of morality?

The distinction between the two understandings of morality described above parallels J.L. Mackie's contrast between morality in the "narrow" and in the "broad sense." If morality in the broad sense incorporates and, where necessary, assesses the relative force of all the reasons for or against doing anything, morality in the narrow sense includes considerations from some limited range. According to Mackie, morality in the narrow sense is "a system of a particular sort of constraints on conduct-one whose central task is to protect the interests of persons other than the agent and which present themselves to an agent as checks on his natural inclinations or spontaneous tendencies to act." 39 Such a conception allows us to think of morality as specialised body of considerations that may be systematised and segregated from others. Thus, it also allows us to conceive of certain zones-for example, perfectly competitive markets, as famously argued by David Gauthier-that are "free" from morality. ${ }^{40}$ Morality in the broad sense does not allow for this type of reasoning.

In this article, I rely on the second (or broad) understanding of morality explained above. I opt for it because, inter alia, I want to emphasise that reasons of self-preservation often do not fill the whole domain of the rationality of action, even in extreme circumstances. Reasons of self-preservation may not render other reasons for action inapplicable in the way that the first (or narrow) sense of morality might

\footnotetext{
39 J.L. Mackie, Ethics: Inventing Right and Wrong (London: Penguin Books, 1977), pp. 106-107.

${ }^{40}$ Gauthier (1986, ch. 4).
} 
allow. Let us first consider a phenomenological example. When an individual is constrained to kill an innocent aggressor to preserve her life, she often experiences some measure of regret, that is, of retrospective horror at what she was capable of. This is not just the horror of having witnessed something unpleasant, or the horror of having been in danger oneself. It is the horror of the agent, the 'what have I done,' which we may all experience at some point in our life, even in circumstances of unusual and enormous pressure. This type of regret can be explained by the fact that morality is not absent from, or inapplicable to, such situations. There are forceful reasons other than reasons of self-preservation weighing against the killing - reasons of justice, humanity, and so forth. The agent who acts contrary to these reasons leaves behind what we may call a moral residue, object of her regret. She may well have been justified in not following these reasons because they were defeated, were supererogatory, or because they and the reasons for self-preservation coexisted while remaining undefeated in virtue of their incommensurability. Be that as it may, she faces a dilemma triggered by the existence of forceful and conflicting reasons, applicable in a way that sits awkwardly with jurisdictional, survival-centric accounts of morality. A similar tension would likely arise if, say, an agent failed to come to the rescue of others, who were left to a horrible fate, to ensure his survival. In the words of Tzvetan Todorov:

Matters of conscience are not at all rare in extreme situations, and their very existence attests to the possibility of choice, and thus of moral life. One might flee such dilemmas because they entail that one freely choose an evil, albeit a lesser one perhaps that might have existed in the absence of choice. They cannot always be avoided, however. ${ }^{41}$

On the basis of the passages quoted in the section above, Hobbes, unlike Griffin, might be able to account partially for such rational conflicts and regret owing to his distinction between what may oblige in foro interno but not in foro externo. A possible interpretation of this feature of

${ }^{41}$ Tzvetan Todorov, Facing the Extreme: Moral Life in the Concentration Camps (London: Phoenix, 2000), p. 36. 
his argument is that morality remains applicable in extreme situations, but that one should not listen to its guidance when deciding how to act. However, even if we grant the relevance of this distinction, Hobbes's overall account remains deficient. Like Griffin's account, it is deficient to the extent that, although self-preservation may be an important value or good in the realm of action, it is often not the only important value or good (even in extreme circumstances). ${ }^{42}$ Many people are prepared to sacrifice their lives, not only for others, but for the sake of other-regarding principles, and it is far from clear that such behaviour is irrational. ${ }^{43}$ That this is no mere theoretical possibility, of interest only in scholarly debate, is clear from many historical situations. Even in the Nazi death camps, where the breakdown of social expectations approximated something like a state of nature, there were many examples of resolute commitment to reasons and norms that defy the survival-centric outlook. For example, an Auschwitz survivor could conclude after all the horror that "at no time was my survival at the expense of anyone else and I had no justifiable reason to feel guilty of not acting in a human manner even in the "darkest" days of persecution." 44 The example of a Polish priest who, in the nightmare of Auschwitz, volunteered to swap places with an innocent individual whom the Nazis had decided to execute, is also to the point. ${ }^{45}$

What could Hobbes and Griffin say of these people who put considerations of justice or charity above their own survival? I am not sure that they could, in all consistency, add anything very enlightening (taking it for granted that it is not helpful to say that they are irrational because these other considerations are "inapplicable”). Hobbes and Griffin might try to say, along with some historians and sociologists, that people trapped

${ }^{42}$ Note that one should not make the converse mistake of thinking that moral considerations in the narrow sense are necessarily finally authoritative in situations where self-preservation is not at stake.

43 See generally C.A.J. Coady, 'Hobbes and "The Beautiful Axiom”', Philosophy 65 (1990) 5-17; Philippa Foot, 'Rationality and Goodness' in Anthony O’Hear (ed.) Modern Moral Philosophy (Cambridge: Cambridge University Press, 2004).

${ }^{44}$ Kitty Hart, I Am Alive (London: Corgi, 1974), p. 153.

${ }^{45}$ This example is reported by Coady (1990, p. 15). 
in settings like concentration camps are usually dominated by the drive to individual survival, and that cases of altruism and principled action are merely anomalies that confirm the rule. However, as I hinted above, a more careful scrutiny reveals a significantly more complex reality. As Jorge Semprun, a Buchenwald survivor, remarks: "In the camps, man becomes that animal capable of stealing a mate's bread, of propelling him toward death. But in the camps, man also becomes that invincible being capable of sharing his last cigarette butt, his last piece of bread, his last breath, to sustain his fellowman." 46 The second (or broad) understanding of morality introduced above allows for a more nuanced explanation of the demands that morality places on us in such situations and, consequently, of how we may justifiably behave. As Anna Pawelczynska, another Auschwitz survivor, observes:

[T]he Ten Commandments did not disappear [in the camps]; they were simply reinterpreted. Murder, for example, could be a moral [qua justified] act if it kept an assassin from carrying out cruel and vicious assignments. Bearing false witness could become a virtuous act if it helped save human lives. To love one's neighbour as one loved oneself was perhaps an excessive demand, but to avoid harming him was not. $^{47}$

An understanding of morality that is non-jurisdictional and flexible, a morality that does not run out and does not get entangled in webs of overly rigid obligations, can account for Pawelczynska's observations. It is also an understanding that provides a perspicuous counterpoint to law. Within the sphere of jurisdiction it claims for itself, law is often understood as a system of rules - or prescriptive generalisations - that are inflexible, to the extent that they do not always make the exceptions and nuances they should make to accord with their underlying justifications. By definition, it is often remarked, rule-based generalisations are somewhat over-inclusive

\footnotetext{
${ }^{46}$ Jorge Semprun, The Long Voyage (London: Weidenfeld and Nicolson, 1963), p. 60.

47 Anna Pawelczynska, Values and Violence in Auschwitz: A Sociological Analysis (Berkeley: University of California Press, 1979), as reported in Todorov (2000, p. 36).
} 
and under-inclusive. Morality, in the broad non-jurisdictional sense in which I shall now use the term, never is. It always applies to whomever it addresses and never goes awry.

It might be relevant to mention here the existence of paradoxical arguments by theorists who, like Michael Walzer, defend the view that morality can never be suspended or ousted. According to Walzer, there are "supreme emergencies" that justify the perpetration of various (all-thingsconsidered) immoralities by government officials. ${ }^{48}$ Supreme emergencies justify these immoralities because they threaten what Walzer deems to be the highest human value, namely, the survival and freedom of states and of the political communities of which they are the instruments. For reasons akin to those expounded above, I doubt the general soundness of this (inconsistent?) position. However, given that my focus in this article is on more discrete individual emergencies, I shall refrain from discussing the point any further and leave the question open for discussion on another occasion.

\section{MORE OR LESS ISOLATED INDIVIDUAL EMERGENCIES AND CRIMINAL LAW}

With such theoretical tools and clarifications in hand, I now want to take a fresh look at the criminal law's relationship with individual emergencies. I want to focus on states of affairs in which such emergencies are inevitable facts of people's lives, but in which the de facto authority of the state is generally not in question. Such conditions prevail in most societies under modern conditions, where there is relative social stability. In many such states, the criminal law, at least in its mala in se dimension, is commonly regarded as giving general effect to some morally important reasons which exist independently of it-e.g. reasons against murdering or harming others, or in favour of respecting others' property. But the criminal law does more than simply enforce pre-existing reasons of this kind, because their exact scope and force are controversial and uncertain. It can and often does serve as an authority that solves coordination problems by

${ }^{48}$ Walzer (2004). 
specifying in more certain terms legal rules which reflect these reasons. ${ }^{49}$ In terms of the normal justification thesis, the criminal law is justified in so proceeding when its subjects are more likely to conform to morality by following the coordinating rules than by determining their behaviour according to their own lights. In some cases, the criminal law may also be justified by the fact that it has a sharper moral judgment than us, especially when it is in a better position to account for all the relevant reasons that apply to us. More importantly, given that human beings are often weakwilled, the criminal law may also be justified on the ground that it helps strengthen our resolve to do what we ought to do, by appealing to our fear of sanctions. How, then, should the criminal law contend with more or less isolated individual emergencies?

\section{INDIVIDUAL EMERGENCIES AND THE SUBDIVISION OF CRIMINAL LAW'S AUTHORITY}

It should now be apparent that if the criminal law, when it attempts to give effect to pre-existing reasons (or to craft new reasons) in its rules, fails to account for significant moral nuances and to give individuals the leeway that morality gives them, it risks making it harder for them to comply with the reasons that otherwise apply to them (or at least being completely unhelpful). This point is meant to be general, but emergencies are paradigmatic scenarios. In emergency situations, deliberation time is typically so scant, opportunities to avoid harm so restricted, the stakes so high and unexpected, that if the law fails to recognize morally justified alternatives and erects authoritative rules that are too rigid and exception-

\footnotetext{
${ }^{49}$ If, in its mala in se dimension, the criminal law sharpens existing reasons by making them more precise and appealing, it also strives, in what academic commentators have termed its mala prohibita or 'regulatory' dimension, to sharpen morality in a more radical way. Mala prohibita criminal law seeks to solve moral problems by creating new reasons for action in the form of legal rules, reasons which would not exist but for the law. For example, the criminal law sometimes imposes labelling requirements to ensure safe food consumption by all. Note that whenever the law creates a new reason, this reason is subject to the same kinds of conflicts as any other reason. Therefore, although I have organized my discussion around mala in se criminal law, mala prohibita, which is merely an extension of the mala in se problem, does not fall outside its scope in any significant way.
} 
less, it risks undermining its claim to legitimacy. ${ }^{50}$ Does this line of argument reminiscent of the moral view introduced earlier entail that we should espouse it as the correct view? In other words, should criminal law account for its ex ante ineptitude in times of individual emergencies by expecting no more than direct reliance on morality?

One might object that I have stacked the cards in favour of the moral view by assuming that the criminal law seeks to give effect to moral reasons and solve moral problems. Could we not say along the lines of the institutional view that, since the criminal law is often an incompetent guide when confronted with individual emergencies, it should simply move out of the way? To borrow Michael Ignatieff's formulation of the claim: "If laws are rules, and emergencies make exceptions to these rules, how can their authority survive once exceptions are made?"51 I believe this challenge to be somewhat artificial (at least with respect to relatively discrete individual emergencies). It is concordant with the normal justification thesis to say that general criminal law regulation can remain legitimately authoritative in the face of individual emergencies, so long as it makes enough space for better situated people-e.g. individuals in the predicament or bystanders - to assess the various reasons that apply to them and act according to morally undefeated ones. In other words, to remain legitimately authoritative in emergency situations (assuming, for the sake of argument, that it is otherwise legitimate, which it may not be), the criminal law may subdivide its authority in favour of people who are better placed to respond appropriately.

\footnotetext{
${ }^{50}$ Here, a consequentialist might add that if the criminal law's subjects know it to reflect morality at least roughly, they may be, if only ever so slightly, more inclined-some might say, more conditioned-to act justifiably in the expectation of ex post facto vindication. However, retributivist and expressivist conceptions of criminal law would reject even this minimal consequentialist assumption, insisting instead that agents can be expected to act in accordance with morality even if criminal law norms do not act as explicit incentives.

51 Michael Ignatieff, The Lesser Evil: Political Ethics in an Age of Terror (Edinburgh: Edinburgh University Press, 2005), p. 25.
} 
In some ways, such subdivision of legal authority in favour of individuals confronted with emergency predicaments is similar to other subdivisions of legal jurisdiction that may be implemented to bolster the law's legitimacy - for example, between the legislature, the executive (and its sub-branches), and the judiciary, or between federal and state/provincial governments. The issue is both political and moral. It is to be settled by the relevant state organs in consideration of, inter alia, the law's general ability to provide assistance in emergencies. As a result, it is intrinsically linked to the (moral) justifiability of the legal rules to which they give shape. When the law's authority is subdivided in favour of its subjects, they are typically allowed to act on various (non-legal) considerations that the law would otherwise have pre-empted. Given the law's limited competence in times of emergency, such an approach may sometimes be the only legitimate alternative available to it. Furthermore, to the extent that no rational agent is ever exempt from morality (even when confronted with emergencies), private delegatees of the law's authority are not left to behave according to their whims. At the very least, they remain subject to their predicament as moral agents, and the law may elect to judge them in this light—some might say, 'on the merits' — ex post facto.

John Gardner explains the delegation point in this way:

So far as the criminal law is concerned all reasons in favour of performing the criminalised action are defeated by virtue of the law's unquestionable and all-embracing authority. It means that one is left with no automatic access to any justificatory considerations, however powerful they may be apart from the law. What the law does, which nevertheless creates a role for some justificatory defences, is to provide us with cancelling permissions to perform, under certain specified conditions, the actions which it criminalises [...] the law's cancelling permissions do not cancel the reasons not to perform the criminalised action, but merely cancel the reasons not to act for certain countervailing reasons. Thus 
justificatory arguments which the law would

So, the criminal law may choose to create gaps-i.e. justificatory defences - in its mandatory qua exclusionary force through which some conflicting emergency reasons may be unexcluded, or admitted, as legally acceptable reasons for action. It is then up to individuals confronted with emergency predicaments to assess the comparative weight and structure of the said reasons, and to decide whether to act on them. From the legal point of view, the person who finds herself outside the predicament-i.e. outside the parameters of the justificatory defence-is subject to the direct authority of the criminal law and its prescriptive rules, whereas the person inside the predicament is granted some practical latitude to decide for herself how to act. ${ }^{53}$

At this stage, some important cautionary remarks and clarifications seem apposite. First, although I suggested earlier that the subdivision of the criminal law's authority in the context of justification defences may, in some ways, be similar to federal divisions of powers, tripartite governmental separation-of-powers, and administrative forms of delegation, one should be conscious of the limits of this analogy. Contrary to what Malcolm Thorburn has recently affirmed, it does not follow from the fact that the criminal law subdivides its authority in favour of private individuals in the context of justification defences that these individuals necessarily "stand in the shoes of public officials to whom this authority belongs" or that they necessarily "claim to be acting in the state's name.” 54 Consider, for example, the defence of self-defence. Private resort

${ }^{52}$ Gardner (1996, p. 116-117).

${ }^{53}$ Note that in many legal systems, the criminal law does not only grant practical latitude to people who are themselves in emergency predicaments, but also to third parties or bystanders who witness emergencies and are in a position to provide assistance.

${ }^{54}$ For the first claim, see Malcolm Thorburn 'Justifications, Powers, and Authority', Yale Law Journal 117 (2008): 1070-1130 at p. 1126. For the second claim, see Malcolm Thorburn 'The Constitution of Criminal Law: Justifications, Policing and the State's Fiduciary Duties', Criminal Law and Philosophy (forthcoming 2009, manuscript on file with the author). 
to such a defence typically becomes necessary when the state, acting through the criminal law system, has failed to stop an attack that it should have stopped. In a sense, the state has let down the self-defender, with the result that she may now have nobody to turn to but herself and, possibly, some (private) bystanders for protection. Thus, instead of claiming to be acting qua public official or in the state's name, the private self-defender who claims a criminal law justification is much more likely to be claiming that, since state and criminal law have failed her, they would have no legitimate business prohibiting her-and possibly condemning and punishing her-from seeking to do what they should have done.

As noted by John Gardner in the passage reproduced above, justification defences are essentially legal permissions that allow those who benefit from them to act upon reasons that are otherwise legally excluded. These defences recognise that some latitude of action should be left to their beneficiaries, and it is in this sense that they constitute subdivisions of the law's authority. However, justification defences are not power-conferring norms per se. ${ }^{55}$ They do not confer normative powers on individuals to bring about changes in their own normative position or in that of others. Examples of this second type of norms would be the criminal law rules that, in various jurisdictions, empower justices of the peace to authorise arrests and searches. Thus, whereas justified private self-defenders are typically granted some legal latitude qua authority to infringe relevant criminal law prohibitions, they do not necessarily exercise a legal (or state) power when doing so. I say 'necessarily' because legal powers and legal permissions to infringe criminal duties sometimes come together harmoniously, like in the case of police officers who, in numerous jurisdictions, perform forceful warrantless arrests of recalcitrant individuals that are at once legally valid and justified. However, the relationship between the two kinds of norms is merely

\footnotetext{
${ }^{55}$ My talk of subdivision or delegation of 'authority' or 'practical latitude' in the context of justification defences should always be understood with this caveat in mind. A social contract theorist might argue that the term 'authority' is ill-chosen, since authority that is delegated back to those who conferred it stops being authority as such. While noting the point, I choose not to make much of it here. I consider that the relevant distinction is sufficiently clear in the text and shall continue to use the said terminology in what follows to highlight instructive aspects of the analogy. On the distinction between permissive and power-conferring norms: Raz (1990, pp. 85-106).
} 
contingent - $\mathrm{a}$ fact that Malcolm Thorburn seems to overlook when he claims that all justified self-defenders exercise state powers. Note further that difficulties with Thorburn's analysis do not stop here, since it is not even clear that individuals who do exercise legal powers always do so qua public officials or in the state's name. Consider, for example, the criminal law norms that empower individuals to consent to what would otherwise be criminal interferences with their own interests. Do individuals who invoke such norms to grant access to their property or body to others always, if ever, invoke them qua public officials or in the state's name? Thorburn attempts to distinguish the legal power to consent as sui generis, but if his underlying argument is genuinely that legal authority is synonymous with state authority and vice-versa, he still has some explanatory work to do. ${ }^{56}$

All that being said, it remains the case that the subdivision-ofauthority approach to the legitimacy of criminal law in the face of individual emergencies has a significant explanatory potential. In countries with Common Law traditions, and also to a large degree in civilian jurisdictions, talk of subdivision of competence usually goes handin-hand with talk of judicial review of the acts and decisions of the delegatees of the law's authority, such as the executive and legislative branches of government. In common parlance, the law might be said to check and balance itself to ensure that its actions remain legitimate. Such talk usually includes questions of jurisdiction, discretion, comity, standards of review, and so on. The analogy with this type of delegation helps understand why individuals who confront an emergency may be subject to various types of ex post facto judicial control for their deeds. Like for the legislative and executive branches, ex post facto control may happen according to different standards of review, which may vary according to considerations of relative expertise, of role, of the nature of the interests at stake, of unusual circumstances, etc. Thinking of the judicial review of private emergency responses on the basis of varying standards of review opens the door to an explanation of why, in many countries, the criminal law chooses to recognize, in addition to justifications, some non-justificatory excusatory claims. When facing an emergency, a person will sometimes overstep her jurisdiction, like in cases

\footnotetext{
${ }^{56}$ See Thorburn (2008, pp. 1113-1116).
} 
of excessive self-defence or in some excusatory cases of duress, or reasonably but mistakenly assume that an emergency exists and react as if it did. Although all-things-considered wrong, such behaviour might well be judged 'reasonable' by a reviewing court and, therefore, not criminally blameworthy or deserving of punishment.

\section{EMERGENCIES, DIVERSITY OF DEFENCES, AND STANDARDS OF REVIEW}

Of course, since criminal law defences are not power-conferring norms as such, analogies with judicial review of legislative and executive action can only be imperfect. However, the ability of such analogies to highlight the fact that justification defences may not be the only defences relevant to emergency predicaments is certainly non-negligible. Justification defences, as I have so far assumed, may provide morally-warranted latitude to individuals in emergency predicaments to decide whether and how to act on specific reasons that are otherwise criminally excluded. They provide practical latitude relative to criminal law norms, but only insofar as those who claim such defences appreciate unexcluded reasons correctly and respond fittingly. Indeed, when recognising a justification defence, the criminal law does not allow incorrect appreciations and excessive responses. What should the criminal law make of emergency appreciations and responses which, although wrong, all things considered, are still quite 'reasonable' or 'understandable' in the circumstances?

As I suggested above, various legal systems answer this query by recognising an additional category of criminal law defences-i.e. excuses. For example, the German Criminal Code (Strafgesetzbuch) recognises both a defence of "necessity as justification" and a defence of "necessity as excuse.” The first one unexcludes certain reasons for action and allows individuals to respond to them proportionately:

Whoever, faced with an imminent danger to life, limb, freedom, honor, property or another legal interest which cannot otherwise be averted, commits an act to avert the danger from himself or another, does not act unlawfully, if, upon weighing the conflicting interests, in particular the affected legal interests and the degree of danger threatening them, 
the protected interest substantially outweighs the one interfered with. This shall apply, however, only to the extent that the act is a proportionate means to avert the danger. ${ }^{57}$

"Necessity as excuse," on the other hand, provides extra leniency for what "could be expected [of the agent] in the circumstances." 58 This second defence does not affect the wrongful character of the impugned action, which remains "unlawful," but, if successfully-invoked, negates the agent's liability to be punished. Likewise, the German Code recognises a defence of "necessary defense" that negates the "unlawfulness" of resort to force when one is "required to avert an imminent unlawful assault from oneself or another," and a defence of "excessive necessary defense” for situations in which "the perpetrator exceeds the limits of necessary defense due to confusion, fear or fright." "59 Like necessity as excuse, excessive necessary defence only negates the perpetrator's liability to be punished, not the unlawfulness of her deed. Now, various other legal systems play fast and loose with the distinction between justification and excuse. Consider the British treatment of self-defence. As Lord Woolf states in the case of $R v$ Martin:

A defendant is entitled to use reasonable force to protect himself, others for whom he is responsible and his property [...] In judging whether the defendant had only used reasonable force, the jury has to take into account all the circumstances, including the situation as the as the defendant honestly believes it to be at the time, when he was defending himself. It does not matter if the defendant

\footnotetext{
57 Strafgesetzbuch, $\quad$ s. 34 (Germany), online: <http://www.iuscomp.org/gla/statutes/StGB.htm\#32> (English translation provided by the German Ministy of Justice).

${ }^{58}$ Strafgesetzbuch, s. 35.

${ }^{59}$ Strafgesetzbuch, ss. 32-33.
} 
was mistaken in his belief as long as his belief was genuine. $^{60}$

Similarly, in Canada, one of the central features of the "justification" of self-defence is that the self-defender "believes, on reasonable grounds, that he cannot otherwise preserve himself from death or grievous bodily harm." 61

Building on his understanding of justification defences as delegated legal powers, Malcolm Thorburn infers from this second set of examples as well as several others that prima facie criminal conduct should be held "justified so long as the relevant person has validly decided that it is justified, based on the facts available to him in the circumstances." ${ }^{62}$ Thus, according to Thorburn, the appropriate standard of review for claims of justification "is one of reasonable belief at the time rather than correctness after the fact," and the proper role of reviewing (trial) courts is merely to control "exercise[s] of discretion for procedural and jurisdictional flaws and not to decide the issue de novo."63 In my view, Thorburn's insistence on a unique, epistemically-grounded standard of reasonable belief and blanket rejection of correctness standards of justification is, once again, notably lacking in nuance-a mistake which seems to stem at least partly from in his derivation of an ought (what the standard of review for justification defences should be) from an is (the structure of defences in some, Anglo-American, legal systems). An investigation of the emergency problématique reminds us that his approach is unsatisfactory, at least theoretically speaking, in that it tends to obscure fundamentally different ways in which emergencies may affect our moral environment and put our exercises of rational agency under pressure.

\footnotetext{
${ }^{60} R v$ Martin (Anthony) [2001] E.W.C.A. 2245 (English Court of Appeal), para. 4-5.

${ }^{61}$ Criminal Code of Canada RSC ch C-46, s. 34(2)(b).

62 Thorburn (2008, p. 1110).

63 Thorburn (2008, pp. 1110, 1126, 1129).
} 
As I have now emphasised several times, emergencies may modify people's undefeated reasons for action and, thus, alter the courses of conduct in which they can justifiably engage, morally speaking. To bolster its claim to moral legitimacy, the criminal law may recognise that individuals who, in the pressure of the moment, are better situated to appreciate their undefeated reasons, are allowed to assess and act on them directly. It can do so by granting them justification defences that are sufficiently broad to accommodate their morally permissible emergency responses. However, since, in the face of an emergency, time is always scarce, opportunities to access and weigh epistemic particulars tend to be limited, and emotions typically run high, one's ability to assess correctly and respond fittingly to reasons for action may be affected. As a result, one may exceed the legitimate boundaries of available legal permissions. When, in such a situation, someone still manages to act in ways that meet the minimal expectations of virtue and skill that befit their role(s) in society, the nature of the interests at stake, their contribution (or absence of contribution) to bringing about their predicament, and so forth, a strong case may be made that the criminal law should also recognise it, excuse them and, to that extent, refrain from blaming, censuring, or punishing them. The important point here is that, at some relevant point in the past, all excused individuals responded incorrectly to the reasons for action that applied to them. They perhaps did so on the strength of beliefs or emotions which, given situational exigencies, were morally understandable. However, in some way or another, their responses were wrong and impermissible.

At this point, an objector may interject that if one accepts correctness as the standard of justification, then, of course, it follows that actions on the strength of reasonable, though erroneous, beliefs can only be excused. Yet, the objector may persist, is it not so often indeterminate whether or not given reasons for action obtain that reasonable beliefs about the world are realistically all we have? And insofar as this is the case, does it not mean that morality and criminal law should make do with them when assessing the doings of agents? There is certainly matter for discussion here, but it is important not to exaggerate the objection. Note, first, that reasons for action are facts, that all facts, by their very nature, have an objective existence, and that the existence of many of them is evident. Consider the following example. The French Penal Code recognises that a defence is available to a self-defender if, when 
“confronted with an unjustified attack upon himself or upon another, he performs at that moment an action compelled by the necessity of selfdefence or the defence of another person, except where the means of defence used are not proportionate to the seriousness of the offence." ${ }^{24}$ On its face, this defence focuses on cases in which someone is being attacked and allows for repelling action at that moment. Could one seriously deny that an innocent Parisian baker who is being stabbed with a dagger by a hostile gangster and, there and then, resorts to proportionate force in selfdefence is incorrect in assuming that he has an objective and, in that particular case, undefeated reason to do so?

Admittedly, complications crop up when one starts to consider events which are likely to take place in the future. Such complications are worth mentioning since all emergencies involve at least some risks of future harm (in addition to any harm that may already have been occasioned), and these risks are often held to justify otherwise impermissible behaviour. One criminal law theorist, Victor Tadros, uses this kind of hypothesis to mount a challenge against the contention that claims of justification, both moral and legal, should be assessed on the basis of a standard of correctness, as opposed to a standard of reasonable belief (or, as he puts it, a standard of objective appearance). According to him, "it is always the case, where one takes a risk and things turn out badly, that there is a further fact about the world that one could have known that would make the risk not worth taking." 65 Yet, he says, "Our sense that the taking of a risk is justified is often robust against the outcome of the taking of that risk. If things do not turn out as the risk taker hopes, that does not establish that the taking of the risk was unjustified." Tadros claims that only a standard of reasonable belief-or objective appearance-can account for the fact that risk takers can be justified irrespective of the outcomes of their actions or of whether the risks on the ground of which they acted would, in fact, have materialised.

\footnotetext{
64 Code pénal (France), Art. 122-5, online: <http://www.legifrance.gouv.fr/html/codes_traduits/code_penal_ textan.htm> (English translation supervised by John Rason Spencer).

65 Victor Tadros, Criminal Responsibility (Oxford: Oxford University Press, 2005), p. 286.
} 
I believe that Tadros moves too fast and that a brief foray in the theory of reasons helps to show why. On the one hand, theorists who maintain that there is at least some degree of causal determinism in our universe generally recognise that there are such things as objective risks (or probabilities) of harm, that these objective risks are facts and that, at least in principle, they may constitute reasons for action. Stephen Perry, who is one such theorist, defines "objective risk" as "the stable relative frequency that may be exhibited by the occurrences of a given attribute [e.g. harm] within a series of events or objects in the physical world, where those events or objects can in an appropriate way be characterized as similar." 66 To the extent that such an objectivist conception is sound, a risk can ground and justify action, and there is no necessity to bring in epistemically-grounded standards of appearance or belief to account for Tadros's intuition about justified risk-taking. One is justified insofar as one responds suitably to an undefeated risk. Of course, the criminal law, wearing its coordination hat, may seek to specify the scope of risks qua reasons for action that it unexcludes when recognising a justification defence. However, this is no objection to the legitimacy of its claim of authority, so long as it makes sufficient space for better-situated individuals to respond to undefeated risks if they so elect. If sound, this account helps explain why, for example, the German Criminal Code allows, under the defence of "necessity as justification" (reproduced above), for the avoidance of an "imminent danger" in circumstances where "the degree of danger" and nature of the protected interest(s) threatened "substantially" outweigh the interest(s) interfered with.

Of course, theorists who admit of the existence of objective risks may also admit of more epistemic, or belief-based, conceptions of risks. Perry, for example, speaks of epistemically-assessed risks as human "estimates of objective probabilities that are based on, and relative to, a given body of evidence." 67 The important point is that such accounts of epistemic risks are generally conceptually parasitic upon the existence of

\footnotetext{
${ }^{66}$ Stephen R. Perry, 'Risk, Harm, and Responsibility' in D.G. Owen (ed.) Philosophical Foundations of Tort Law (Oxford: Oxford University Press, 1995), pp. 321-346 at p. 323.

${ }^{67}$ Perry (1995, p. 325).
} 
objective risks. It is objective risks that provide the ultimate benchmarks against which the correctness of epistemic estimates is to be tested, so that, at least in principle, reasonable beliefs about risks are not the only, let alone the most accurate, grounds of action that we have. No doubt, reasonable beliefs qua estimates of objective risks can often be useful guides to justified action, but they are not the be-all and end-all of riskbased rationality and may sometimes be quite deceptive practical guides.

Much more could be said about accounts of risks that ultimately rest on deterministic views of the world. However, I think I have said enough to shift the burden onto Tadros to provide a counter-argument. If determinism is false, on the other hand, and causal processes in our universe are fundamentally random, then the notion of an objective risk qua stable relative frequency qua fact of the world may not make much sense. Such a conclusion, it seems to me, would tend to bolster Tadros's position insofar as epistemic beliefs, however deluded, might then be all there is to practical rationality (aside from facts about the world as it is at any given moment). Surprisingly, though, Tadros insists that "even if determinism is false [...] there are facts about what will happen in the future as well as facts about the world as it is now."68

Are there really non-probabilistic present facts about the future and, if so, what are they? At first glance, we might be tempted to assume that Tadros is referring to how things actually turn out in the future, but, if we are consistent with the logic of indeterminism, we are forced to the conclusion that how things turn out later will only become factual when they do indeed turn out. In other words, how things will turn out later cannot be a reason for action now. Tadros does not go down this obviously fallacious path and, rather, chooses to characterise some present "appearances" about how things will turn out as objective facts which may constitute undefeated, justificatory reasons for action. He claims that appearances are objective when they are "appearance[s] to any believer."69 However, as John Gardner remarks, Tadros can only possibly be referring to believers with reasonable beliefs, not to those who are delusional and

\footnotetext{
${ }^{68}$ Tadros (2005, p. 286).

${ }^{69}$ Tadros (2005, p. 284).
} 
fail to see things as they appear to others. ${ }^{70}$ Thus, as I have been assuming throughout, Tadros is really advocating a standard grounded in epistemic belief-belief substantiated by evidence and, thus, reasonable belief perhaps, but belief nonetheless, and belief that may be erroneous. ${ }^{71}$ Indeed, insofar as our beliefs about the future can ever be reasonable in an indeterministic world, which remains unclear to me, they are still not objective facts about the world, irrespective of how substantiated they may be.

Do these observations entail that if indeterminism is true, individuals can never hope to respond correctly to threats of future harm? I think that such an inference would be unwarranted. At the very least, one may sensibly say that our actions could be held to correspond to correct assessments of the world ex post facto, at the time when the beliefs on the strength of which they were taken do in fact turn out to be accurate. I am conscious that this answer leaves much undiscussed, but it is sufficient for my purposes. It underscores that even if the future is fundamentally indeterminate, it does not follow that justificatory standards of review have to be grounded in epistemic considerations, as opposed to objective facts of the world. According to both deterministic and indeterministic accounts of the world, morality and criminal law can often assess people's past actions in view of their correspondence to objective facts, and this possibility should not be obscured by an exclusive focus on more subjective epistemic (or, for that matter, affective) considerations.

Of course, these additional considerations should not be ignored and may sometimes influence quite radically how the criminal law should treat its subjects. Many permutations as to their significance are conceivable. For example, it may be that no defendant could have known and done better than they did at the time of action due to radical

\footnotetext{
70 John Gardner, Offences and Defences: Selected Essays in the Philosophy of Criminal Law (Oxford: Oxford University Press, 2007), p. 260.

71 As Tadros himself recognises when discussing the case of a glass full of petrol that appears to be a glass of gin, 'it is difficult to see how to drive a wedge between having good reason to believe that the stuff is desirable to drink and having good reason to drink it.' Tadros (2005, p. 285).
} 
indeterminacy about the future. ${ }^{72}$ Alternatively, it may be that a defendant could in principle have known and done better but that people in her kind of predicament should not be expected to. It may also be that a defendant knew better, but that, in the circumstances, she quite understandably felt inclined to act differently. Be that as it may, my point is that, conceptually speaking, it is far from senseless to confine these considerations to a realm (or realms?) distinct from that of correctness and all-things-considered justification - say, the realm of excuses. Irrespective of the soundness of deterministic positions, this distinction is central to moral life and should not be overlooked. It is true that many legal systems do not make the distinction or do not make it systematically and that, sometimes, not much hangs on it at the level of penal consequences. However, the existence of untidy approaches should not be taken to mean that no significant distinctions lie beneath them, and that the law could not legitimately treat individuals differently on their basis.

\section{THINKING SOME MORE ABOUT THE NEED FOR EMERGENCY-RELATED LEGAL LATITUDE}

The many controversies that surround the debate about the soundness of (in)determinism as a theory could easily derail my inquiry. The debate is deep and a discussion of its ramifications for criminal law would require a much longer and focused study. So, for the sake of simplicity and to allow me to recentre my investigation effectively on individual emergencies and the delegation insight that I have been exploring, I shall continue to speak as if the determinist-objectivist view of the world were true. I shall also seek to avoid getting bogged down in convoluted discussions about standards of review by focusing mostly on justificatory cases, making allowance for some precisions about the excusatory realm when they matter most, like in the first few paragraphs that follow and in the last section of the article, as well as for further discussion on another occasion.

(i) Distinguishing practical and interpretive latitude

${ }^{72}$ Notice, however, the supect tension between this indeterministic position and my earlier observation that, generally speaking, there are no such things as 'moral black holes.' 
A few additional clarifications about legal grants of emergency latitude seem warranted. The first concerns the nature of such grants. As I contended before, when the criminal law grants us justification defences in recognition of its inability to facilitate our compliance with reason, it grants us practical latitude - that is, latitude to act in ordinarily prohibited ways. Of course, justifications are not the only ways in which the criminal law can grant us latitude. As I emphasised before, it can also grant us excuses. The difference is that grants of excuses are not grants of practical latitude, but grants of interpretive latitude. When recognising an excuse, the criminal law recognises that individuals-notably, individuals confronted with exigent predicaments like emergencies-sometimes deserve to be judged, within reason, according to their incorrect epistemic or emotional interpretations of the world. In lawyers' terms, one may say that questions of legal justification are questions of law-i.e. the law should relax its claim of authority and not make this or that action unlawful-whereas questions of legal excuse are questions of fact-i.e. facts should not be treated as they are/were, but as how, within reason, they were interpreted. Admittedly, this distinction can sometimes become blurred, and not only because legal systems may decide to mix both types of considerations in the context of specific defences. The distinction may be morally blurred.

I initially spoke of the need for legal delegation of practical latitude in emergency situations in relation to Joseph Raz's thesis about the normal justification of authority. The idea is that the criminal law should grant us justificatory latitude when it is unable to help us comply with reason better than if we acted according to our own lights. Note, however, that it is unclear whether the normal justification thesis is satisfied whenever the law turns out to have better captured what we ought to do, or whether the law's rational advantage needs to be epistemicallyascertainable at the time of action. The tension is perhaps at its starkest in cases of objective risks of harm that are unknowable even in principlethat is, unknowable to everybody given their position, including the law itself-but which the law happens to pre-empt correctly (as confirmed ex post facto). In such cases, the law could not say that it was better-placed than anybody else at the time of action, yet, as it turns out, its guidance was in line with reason. When evaluating people's conduct ex post facto in such circumstances, should the criminal law consider providing 
justificatory latitude since it could not know better than them how to act at the time of action, or should it merely make excusatory concessions since, as it turns out, people would have complied with reason better by deferring to it? I am not introducing this layer of complexity to attempt to solve it here, but to acknowledge that my approach may have some limits: there may well be borderline cases of justifications and excuses tied to deep indeterminacies in rationality. These borderline indeterminacies may be solvable; I do not know. But even if they are, such resolution would require much more work than I can afford to do here. In my view, it is also peripheral to a study of the practical relationship between individual emergencies and criminal law.

(ii) Revisiting Fletcher's insights

My next set of clarifications brings us back to the central issue of the significance of individual emergencies as such: Should the criminal law only confer practical latitude to its subjects in connection with individual emergencies? Should it do so with respect to all emergencies? George Fletcher's answer to this question, you will recall, is that when the law is unable to provide adequate ex ante guidance because imminent and extraordinary circumstances necessitate a swift response, it should give individuals some margin of manoeuvre to decide how to act. The law might sometimes be able to account for such situations in its normal rules, but this might be at the cost of an intolerable degree of vagueness. Law, perhaps especially in deliberative democracies but also in more monolithic regimes, is typically a slow-moving institutional instrument, ill-suited to assess the particulars of individual emergencies and convey specifically relevant guidance in a timely fashion. Drawing on his experience of American law, Fletcher gives the example of the criminal law's posture in relation to the countless situations in which people may be justified in infringing its rules out of necessity:

The standard of necessity [...] is defined generally to exact a comparison of the costs and benefits of following the nominal prohibition of the law. Imagine the vagueness of a crime defined to incorporate this cost/benefit judgment. It would read something like: Don't take things belonging to 
another unless, on balance, it is better for society to do so. ${ }^{73}$

According to the ideal of the rule of law, it is crucial that those who are subject to the criminal law's authority be capable of being guided by law, so that they can deliberately steer their lives around it and avoid the stigma and disruption of its adverse normative consequences-e.g. blame, social censure, punishment, and the like. ${ }^{74}$ If the criminal law cannot guide its subjects in this way, it should refrain from seeking to do so authoritatively, and grant them instead sufficient latitude to follow the guidance of morality (which, as we have seen, cannot be criticised for being vague, even when it is).

Vague defences may enable the criminal law to provide such latitude. Consider the defence of necessity to which Fletcher is referring. In principle, since it is formulated in terms of an indeterminacy of aim, the defence allows criminal defendants to invoke an infinite range of undefeated reasons that occasion a genuine necessity (as circumscribed by the defence). Since new such reasons - that is, undefeated reasons of necessity that have not been anticipated-can always arise, the defence provides significant latitude relative to criminal prohibitions. Fletcher first hinted at this point almost three decades ago, when he wrote that the distinction between criminal offences and defences "might bear on the analysis of permissible vagueness in legal norms." 75 However, he did not integrate his analysis with the theory of authority nor with any discussion of morality. Doing so allows us to see more clearly why his distinction matters, and why legal categories may suitably be left more elastic with respect to defences than with respect to authoritative, guidance-oriented definitions of legal wrongs.

${ }^{73}$ Fletcher (1993, p. 180). Note that I am not taking any stance on the correctness of the moral position as formulated here.

${ }^{74}$ This is not to say that any degree of vagueness violates the rule of law condition. As argued by John Gardner, vague criminal law rules may pass muster if they meet a reasonable threshold of 'moral clarity.' John Gardner, 'Rationality and the Rule of Law in Offences Against the Person', Cambridge Law Journal 53 (1994): 502-523 at p. 513.

${ }^{75}$ G.P. Fletcher, Rethinking Criminal Law (Boston: Little Brown, 1978), p. 555. 
The rationale behind Fletcher's (in)competence argument (as developed and refined in this article) also helps us understand why the existence of an emergency is not a condition sine qua non of justification defences. $^{76}$ Traditionally, common-law jurisdictions (and several civil law ones) have qualified the availability of many defences with an 'immediacy' or 'imminent threat' requirement. This requirement, some persist in arguing today, is needed to uphold the rule of law: whenever possible, threatened individuals should look to the law for guidance and protection, instead of resorting to self-help. Whenever doable, they should call upon the protection of public officials or seek the guidance of the courts. However, it is possible to conceive of many non-emergency situations that may render law and legal officials as incompetent as in emergency cases. Consider non-immediate threats that make it psychologically impossible to have recourse to state authorities-e.g. some situations of prolonged domestic violence. Consider also nonimmediate threats made in situations in which reaching out to the outside world, and a fortiori to law and state, is physically impossible-e.g. protracted hostage takings or, simply, old age. Thus, whereas some jurisdictions still retain 'immediacy' or 'imminence' as a precondition to the availability of several defences, others have opted to jettison it in many cases. $^{77}$ In the latter jurisdictions, the issue is now often regarded more broadly as a question of reasonable opportunity to obtain reliable legal guidance or official protection-or, in other words, as a more broadlyconstrued issue of appropriate latitude for action in exigent predicaments.

So, Fletcher's insights can take us quite far when reinterpreted in light of the legitimacy of the criminal law's authority. As suggested, criminal law may remain legitimately authoritative in the face of private emergencies so long as it makes enough space for individuals to respond

\footnotetext{
${ }^{76}$ The issue is much less pressing in relation to the excusatory realm, where the existence of an emergency tends not to be regarded as a precondition. As I suggested earlier, the issue at the excusatory level is one of interpretive latitude, and not of practical latitude in light of specific events.

77 One example is that of Canada, where courts have explicitly done away with the immediacy requirement in cases of duress qua justification and qua excuse: $R v$. Ruzic [2001] 1 S.C.R. 687577 (Supreme Court of Canada).
} 
fittingly to the reasons for action that apply to them (other than allegedly authoritative legal reasons). It may grant them such extra space by recognising ex post facto-i.e. through the intervention of courts-that they are entitled to a justification defence for their prima facie infringement of its rules. Typically, criminal law makes such recognition possible by deeming generic types of exigent considerations-e.g. selfdefence and some other forms of necessity and duress - to be permissible grounds of derogation from its rules. It then authoritatively instructs judges and juries to recognise them as exculpatory factors insofar as they were fittingly acted upon. Morally understandable yet impermissible responses may also be accounted for by defences that instruct judges and juries to consider epistemic and affective (excusatory) factors relevant to assessments of criminal blameworthiness and desert. Although distinct, justificatory and excusatory considerations are sometimes assimilated, with the result that related legal defences and their exculpatory standards tend to vary significantly between legal systems. That being said, since rule-of-law considerations do not apply to judges in the same way as they apply to private individuals, the parameters of defences may be couched in vaguer terms-e.g. in terms of unjustified threats, of necessary and proportionate conduct, of reasonableness, and so on. When such language is used, criminal law judges are given some margin of manoeuvre to adjudicate cases on their (moral) merits. They may then vindicate the courses of conduct of those who were better-placed than the law to assess the reasons for action applying to them, as well as show appropriate leniency to those who deserve it despite having failed to appreciate or respond to their reasons for action correctly. ${ }^{78}$

(iii) Horder’s limiting principles

My third and final set of observations has to do with a number of principles, recently formulated by Jeremy Horder, that are meant to restrict

\footnotetext{
${ }^{78}$ Here, I do not mean to deny that in many Common Law jurisdictions, criminal law defences may be recognised by statute and by the common law. I also do not mean to deny that both civilian and Common Law judges may sometimes, at least in principle, interpret criminal legislation in ways that recognise defences not otherwise recognized explicitly. Of course, such creative interpretations may also be limited by jurisdictionspecific rules to that effect. Compare: Timothy Endicott, 'Interpretation, Jurisdiction, and the Authority of Law’, APA Newsletter 6 (2007): 14-19 at p. 18.
} 
the criminal law's recognition of justification defences. Focusing on paradigmatic types of individual emergencies, Horder suggests the following constraints. First, the situation in which the individual acts should be a situation in which her "needs cannot be reasonably addressed, even in principle, through official channels."79 Second, the situation should be one that "may never be repeated," and third, the dilemma faced should have "no wide-ranging and complex [policy] implications for analogous situations." 80 Although useful, Horder's principles should not be taken to represent more than mere rules of thumb. ${ }^{81}$ For example, as I indicated above, the availability of official recourses "even in principle" should not be read so stringently as to disregard the genuine psychological and physical limitations of individuals in exigent predicaments, as well as the reliability of the legal guidance and official recourses available.

With respect to the second principle, it is true that that the recurrence and predictability of a given type of emergency may sometimes allow the law to develop some expertise or coordination ability that enables it to provide clear and legitimate ex ante authoritative guidance via its rules. As for the third principle, it may also sometimes be the case that the law has more resources than the individual to assess the complex moral ramifications of a given emergency, and is therefore in a better position to determine which course (or courses) of action are undefeated. Horder gives the example of doctors who have the option-sometimes repeatedly_of performing death-dealing transplants that kill one patient to try to save the life of many others. No doubt, he has a point. The law is sometimes more competent than its subjects to assess the moral ins and outs of situations, even emergencies. In intricate settings such as the provision of emergency healthcare, the criminal law and legal officials who speak and act on its behalf may sometimes be able to set reliable $e x$ ante parameters for doctors, convey guidance to them effectively through rules, and lead them to better conformity with reason than if they acted

\footnotetext{
${ }^{79}$ Horder (2000, pp. 177, 180).

${ }^{80}$ Horder (2000, pp. 180-182).

${ }^{81}$ Horder (2000, p. 184) acknowledges it himself when he states that a justification defence may exist where one or more of his conditions have not been met.
} 
urgently according to their own lights (even if they did so with the best of intentions). Nonetheless, the previous discussion teaches us that the criminal law should refrain from framing its guidance in absolute terms and from omitting to recognise (moral) justifications, except when it genuinely assesses that to do so favours better compliance with reason. When it errs, the law runs the risk of being branded harsh and illegitimate, and to be systematically disobeyed by morally-abiding individuals.

Consider the example of a poor and racially segregated neighbourhood situated in an otherwise stable state. Tensions run high. Racially motivated attacks are frequent and the state is unable to prevent a fair number of them. Self-defence is often perceived as retaliation, engendering an escalation in acts of violence. In this scenario, emergencies are "recurring" and self-defensive responses to them may have "wide-ranging implications"-e.g. growing loss of faith in state protection mechanisms, increased risks of riots and wide-scale violence, and so forth. Yet, it is questionable whether the criminal law could legitimately omit to vindicate genuine acts of self-defence, even if it thus sought to send out a message. Conviction, followed by executive pardon, might be an appropriate response to the morally complex case of the doctor who genuinely_-some might say, admirably - tries to save many by killing one, but thus (let us assume) acts unjustifiably and unexcusably. ${ }^{82}$ However, the conviction and stigmatisation of a morally

${ }^{82}$ The judgement in the famous case of $R v$ Dudley and Stephens [1884] Q.B.D. 273 may be explainable along analogous lines. Three men and a boy were cast adrift in an open boat with very little food and water. After eighteen days, when all were starving and the boy was the closest of the four to death, two of the men killed him, and all three fed on the body. Four days later, and nearly to the point of death, the three men were rescued. Though the jury found that they could not have survived except by acts of cannibalism, the judgement in the case was that the killing of the boy was not necessary, and that it therefore amounted to murder. According to the decision of Lord Coleridge, the boy was killed because he was the weakest and offered no resistance; but any of the men were appropriate to kill if the boy was, Lord Coleridge held. If the decision to kill was always to be left to the subjective judgement of the people affected in a case where all but one could survive, the judgement continued, the weakest would have the least good chance, when what they deserved was an equal chance. Again, according to the judgement, it was possible, in some sense, that all three could have been picked up before any died, so that it was unnecessary for anyone to be killed. Although Lord Coleridge's take on what amounts to Horder's first principle-i.e. the threshold of official intervention-seems unduly rigid, the complexity of the moral landscape faced by the seamen is indisputable. In cases of this type, one might argue alongside Horder that a conviction followed by an 
justified, better-situated self-defender-who, let us assume, was fully aware and in control of what he was doing-would most likely amount to an abuse of authority by the law. When deciding which justification defences to recognise, each legal system may reach its own more or less legitimate conclusions. It ought to consider its competence alongside all other reasons that may militate for or against subdivision of its authority, such as prior fault on the part of the individual in the predicament, the quality of the various opportunities available to her (such as retreat, possibility of effective ex post facto redress, or compliance with minimally harmful coercive threats instead of resort to lethal force), significant ramifications for society as a whole, et cetera. That said, most criminal law systems nowadays acknowledge the legitimacy-related need for at least basic individual emergency delegation in the form of justificatory defences, such as self-defence, necessity, and some forms of duress, and tend to supplement them with some excusatory latitude at the edges.

\section{A Brief Note ABout Generalised EMERGENCIES}

My discussion in the previous section did not address more generalised and disordering emergencies, such as civil wars, violent revolutions or widespread natural disasters. In addition to confronting vast arrays of people in the form of countless individual emergencies, such situations often constitute emergencies for the law itself, and a fortiori for the criminal law. When, for whatever reason, a generalised emergency undermines a legal system's de facto authority to the extent of rendering it largely inefficacious, it challenges this legal system's very existence and continuity. HLA Hart famously conveyed the point as follows:

From the inefficacy of a particular rule, which may or may not count against its validity, we must distinguish a general disregard of the rules of the system. This may be so complete in character and so

executive pardon might be preferable to the recognition that the defendant is entitled to an outright exculpatory criminal law defence. Note, however, that the case is somewhat borderline and that many criticise it for its failure to recognise (at the very least) the excusability of the killing. 
protracted that we should say, in the case of a new system, that it had never established itself as the legal system of a given group, or, in the case of a onceestablished system, that it had ceased to be the legal system of the group. ${ }^{83}$

Hart's point applies as much to collapsing anciens régimes as to governments forced into exile, hopeless insurgencies, and so on. A legal system that is not by and large efficacious in a given community is not the legal system of that community. It is not competent to be such a system and, at best, it only purports to be. Morally speaking, it cannot aspire to make individuals more likely to comply with the reasons that apply to them by asserting a power to disseminate sounder expertise and judgment, or to solve coordination problems, because it lacks that power. Therefore, in extremely disordering emergency circumstances, the institutional view, as I qualified it earlier, may reassert itself: the criminal law may be outright incompetent to regulate individual behaviour. It may not even be able to point efficaciously to morality.

What one must grasp here is that legal retreat in relatively generalised emergencies will often be a question of degree. The point may seem trite but widespread emergencies may not incapacitate, or have incapacitated yet, the whole of the legal system. When anticipating such extreme scenarios (or in the midst of grappling with them), the law may choose to devise counter-emergency strategies to pre-empt disintegration of its efficacy and legitimacy, as well as to protect the people it normally seeks to guide. Historically, it has sometimes tried to do so in the form of extraordinary 'martial law,' 'war,' 'emergency powers,' or 'emergency management' measures, or simply through ordinary statutory guidance. ${ }^{84}$ The law may also acknowledge that it would be partly incompetent by anticipatorily announcing to what extent it would disclaim competence

\footnotetext{
${ }^{83}$ Hart (1994, p. 103).

${ }^{84}$ For a discussion of the second type of approach, see e.g. S.P. Green, 'Looting, Law, and Lawlessness', Tulane Law Review 81 (2007): 1129-1174.
} 
were certain emergency circumstances to arise. ${ }^{85}$ It may even plan for its own general suspension. As noted by John Finnis, "Sometimes [...] the values to be secured by the genuine Rule of Law and authentic constitutional government are best served by departing, temporarily but perhaps drastically, from the law and the constitution." ${ }^{86}$ That said, a thorough discussion of what the law, and a fortiori the criminal law, may be justified in doing (or not doing) in relation to more extensive emergencies is beyond the ambit of this article. I only mention the possibility of such situations in passing to contrast them with more discrete individual emergencies, and delineate the scope of the argument elaborated earlier. Although clearly needed, an in-depth discussion of generalised emergencies - some might call them 'public emergencies' or 'states of emergencies' - will have to await another occasion. Instead of going down this complex path here, I want to conclude by discussing one last important theoretical controversy about the relationship between individual emergencies and criminal law.

\section{EMERGENCY CONCESSIONS TO HUMAN FRAILTY?}

From the beginning of this article, I have been discussing emergencies in terms of their impact on us as rational, self-determining beings. Even when briefly considering generally disordering emergencies, I referred to them as impacting the reasons that normally apply to us. All theoretical models explored up to now also treat emergencies and appropriate criminal law responses to them as problems internal to rationality. Fletcher's institutional approach is one of legal acknowledgement of incompetence in favour of rational individual judgment, whereas the moral

${ }^{85}$ Such a rationale might, in part at least, explain why murder can only be committed under 'the Queen's peace' under the common law of England. Those who kill enemy combatants in wartime need not argue that they did so for the defence of the realm-or for other lawful reasons-because the offence of murder simply does not extend to their actions. Their argument has already been anticipated in the shape of the prohibitory norm, by means of an exception.

${ }^{86}$ Finnis (1980, p. 275). Conversely, a legal system may also seek to assert retroactively authority which it did not have throughout a generalised emergency. Consider, for example, the Nuremberg trials. 
view presupposes rational beings capable of following the guidance of morality. Obviously, in both models, those who are confronted with emergencies may fall prey to the traps of reason and ill luck. They may commit mistakes about how they ought to act, react disproportionately out of anger or shock, or act immorally out of fear. After all, they are human beings, and reasonable human beings on occasion react in such ways when faced with emergencies. No wonder that the law, like morality, sometimes excuses such behaviour.

However, there is another school of thought that does not account for emergencies, their impact on us, and the appropriate response of the criminal law with the same emphasis on rationality. In a recent assertion of this view, William Wilson writes that "reasons theory has little to say concerning the significant constitutive role played by human frailty in certain key defences. Sometimes our behaviour, though it is not grounded in reason, is afforded an excuse precisely because it issued out of the kind of external crisis which can lead even reasonable people to act unreasonably." 87 As I just pointed out, it is untrue that reasons theory has little to say about human frailty in the face of emergencies. But the frailty which Wilson is referring to is of another type. It is not the frailty of human rationality, but a kind of human frailty that, perhaps, exposes us to becoming less human in times of crisis.

Why less human? As argued by Thomas Nagel in his essay on moral luck, the responsible human self-who we are-seems to disappear if we focus on the influence of what is not under our control. ${ }^{88}$ Aren't our inclinations, capacities, and temperament (constitutive luck), the kind of problems and situations we face (circumstantial luck), the way our actions and projects turn out (outcome luck), and the way we are determined by antecedent circumstances (causal luck), all a matter of luck or, in other words, dependent on uncontrollable causes foreign to the self? It is control that makes us the human beings that we are, and control "consists in the

${ }^{87}$ William Wilson, 'The Filtering Role of Crisis in the Constitution of Criminal Excuses', Canadian Journal of Law and Jurisprudence 27 (2004): 387-418 at pp. 394-395.

${ }^{88}$ Thomas Nagel, 'Moral Luck' in Mortal Questions (Cambridge: Cambridge University Press, 1979), pp. 24-38 at p. 36. 
proper functioning of the person's rational faculty, the proper functioning of the person's ability to recognise and respond to reasons." 89 Put differently, it is our ability to recognize and respond appropriately to the normative aspects of the world-i.e. reasons-which constitutes us as beings capable of making a difference within it (agents), as opposed to purely passive embodiments of luck (patients). It should come as no surprise that Aristotle remarked over two millennia ago that, together with speech, this ability is the main faculty that, in its most developed form, differentiates us from other animal and vegetal life forms. ${ }^{90}$

A metaphorical way of characterising Wilson's view is to say that, according to him, "crises" (or “emergencies"91) often turn us into (less human) animals largely dependent on their uncontrolled surroundings and, at best, able to reason only to serve given ends such as survival-i.e. avoiding injury, eating, reproducing, and so forth. Such a condition is to be understood in opposition to that of (more human) animals who are extensively rationally active within the world, to the point of reasoning and wanting to reason about what their own ends are and should be. For Wilson, behaviour performed while in the former condition is the main type of behaviour which the criminal law ought to excuse, because excuses find their roots in crises, and crises tend to induce that sort of condition. ${ }^{92}$ In his own words, "It is only in response to crisis that it is plausible to claim that our actions are not authentically ours or, if authentically ours," that they are "not actions for which, as decent selfrespecting human beings, we should own up and take responsibility."93

\footnotetext{
${ }^{89}$ Joseph Raz Engaging Reason (Oxford: Oxford University Press, 1999), p. 76.

${ }^{90}$ See especially his Politics $1253^{\mathrm{a}} 7 \mathrm{ff}$ and Rhethoric $1355^{\mathrm{b}} 1 \mathrm{ff}$.

91 Although preferring the word 'crisis,' Wilson sometimes uses 'emergency' interchangeably. Wilson (2004, pp. 401, 409).

92 To be fair, Wilson (2004) recognises that this characterization does not apply to clear cases of rational frailty such as mistakes in justification.

${ }^{93}$ Wilson (2004, p. 389).
} 
When considering our reactions to emergencies, the criminal law ought to be careful not to prematurely dehumanise us in such a way, for the simple reason that, pace Wilson, we often remain rational human beings while facing such situations. If anything, it is a question of respect for human dignity and agency. Take the example of coercive threats qua emergencies which ground the defence of duress per minas - a defence which Wilson does not shy away from discussing in dehumanizing terms. ${ }^{94}$ As shown by the following example excerpted from an essay by Harry Frankfurt, only those of us who answer to reason are vulnerable to such threats:

Jones decides for reasons of his own to do something, then someone threatens him with a very harsh penalty (so harsh that any reasonable person would submit to the threat) unless he does precisely that, and Jones does it [...] One possibility is that [Jones] is not a reasonable man: he is, rather, a man who does what he has once decided to do no matter what happens next and no matter what the cost. In that case, the threat actually exerted no effective force on him. ${ }^{95}$

It might be possible to conceive of coercive threats which might have such a radical impact on us that, if they were uttered to us, would lead us, or some of us, to lose touch with reason. However, if such threats and such reactions to them are conceivable, they no doubt constitute the rare

\footnotetext{
${ }^{94}$ For example, Wilson (2004), writes that 'A person who faces such a sudden crisis [i.e. coercion] cannot always be expected to measure up to socially approved standards of fortitude and reasonableness' (406). Later, he asserts that 'under conditions of extreme externally prompted stress [such as duress] a person's weaknesses must be taken seriously' (410). '[O]rdinary people wishing to rely on cognate defences such as duress,' he concludes, are often 'deprived temporarily of their usual (rule-compliant) character or ability to make appropriate choices’ (414).

${ }^{95}$ H.G. Frankfurt 'Alternate Possibilities and Responsibility' in The Importance of What We Care About (Cambridge: Cambridge University Press, 1988), pp. 1-10 at p. 3.
} 
exception. Coercion operates through the coercee's own appreciation of her reasons for action, and consequently, the more a threat undermines her rational capacities, the less effectively she can be coerced. ${ }^{96}$ I say this with

${ }^{96}$ Derek Parfit makes the point cogently and succinctly with his famous 'Schelling's Answer to Armed Robbery' example, in addition to demonstrating why a precommitment to act irrationally when faced with threats may sometimes be rational. Derek Parfit, Reasons and Persons (Oxford: Clarendon Press, 1984), pp. 12-13. I take the liberty to reproduce it in its entirety below because of its vividness:

A man breaks into my house. He hears me calling the police. But, since the nearest town is far away, the police cannot arrive in less than fifteen minutes. The man orders me to open the safe in which I hoard my gold. He threatens that, unless he gets the gold in the next five minutes, he will start shooting my children, one by one.

What is it rational for me to do? I need the answer fast. I realize that it would not be rational to give this man the gold. The man knows that, if he simply takes the gold, either I or my children could tell the police the make and number of the car in which he drives away. So there is a great risk that, if he gets the gold, he will kill me and my children before he drives away.

Since it would be irrational to give this man the gold, should I ignore his threat? This would also be irrational. There is a great risk that he will kill one of my children, to make me believe his threat that, unless he gets the gold, he will kill my other children.

What should I do? It is very likely that, whether or not I give this man the gold, he will kill us all. I am in a desperate position. Fortunately, I remember reading Schelling's The Strategy of Conflict. I also have a special drug, conveniently at hand. This drug causes one to be, for a brief period, very irrational. Before the man can stop me, I reach for the bottle and drink. Within a few seconds, it becomes apparent that I am crazy. Reeling about the room, I say to the man: 'Go ahead. I love my children. So please kill them.' The man tries to get the gold by torturing me. I cry out: 'This is agony. So please go on.'

Given the state that I am in, the man is now powerless. He can do nothing that will induce me to open the safe. Threats and torture cannot force concessions from someone who is so irrational. The man can only flee, hoping to escape the police. And, since I am in this state, he is less likely to believe that I would record the number of his car. He therefore has less reason to kill me.

While I am in this state, I shall act in irrational ways. There is a risk that, before the police arrive, I may harm myself or my children. But since I have no 
some certainty on the basis of hard evidence provided to us by human history. Nazi tactics, especially concentration camps, were designed to be horrifically threatening, break people's spirit, and dehumanize them as much as possible. Nevertheless, people's reactions to them were often remarkably human and, taken together, are often remembered today as a "triumph of the human spirit.” Anne Frank, who spent 25 months in hiding from the death and destruction endangered by the Nazis, wrote in her diary of happiness. ${ }^{97}$ Countless examples of Jews courageously deciding to run, resist, hide, help, and save one another have also been reported. ${ }^{98}$ If one of, if not the, most horrifically threatening and generalised emergency situation of the last century did not necessarily remove people's capacity to answer to reason, then Wilson, who seems to start from a contrary assumption, might well be wrong.

To be sure, it is true that there might be radical emergency situations which, quite literally, drive us pathologically insane and lead us to be much less, if at all, rational. From an isolated emergency point of view, think of some individual reactions to dangerous phobias. ${ }^{99}$ From a more generalised standpoint, imagine the world after a global nuclear war-a world in which the few survivors lapse into a bestial condition when faced with the need for survival in an environment in which nothing recognizable and usually thought of as necessary for human flourishing remains. Such situations might well be conceivable, but they are clearly not the norm and, if they arise, will most often not be characterized in

gun, the risk is small. And making myself irrational is the best way to reduce the great risk that this man will kill us all.

${ }^{97}$ Anne Frank, The Diary of Anne Frank (New York: MacMillan, 1980), p. 159.

${ }^{98}$ Many such acts are recounted in Charles Lawliss, ... and God Cried. The Holocaust Remembered (New York: J.G. Press, 1994); Elaine Landau, We Survived the Holocaust (New York: Franklin Watts, 1991); Todorov (2000). See also section B2(b)(iii) above.

${ }^{99}$ Consider the example of Winston Smith, in chapter 5 of George Orwell's Nineteen Eighty-Four, when his tormentor O’Brien confronts him with his worse phobia, rats. 'For an instant,' Orwell narrates, 'he was insane, a screaming animal.' Because of his phobia's hold on him, Winston Smith hardly appreciates the reasons that apply to him. To the extent that he does, his appreciation is all but reliable, and leads him to betray his greatest love and commitment. 
Wilson's terms of crisis-triggered “instances of the kind of moral frailty that can lead any of us to behave other than society can expect of ordinary, socially responsible citizens." ${ }^{100}$ Even when we act differently than society would expect in the face of an emergency, it might well be because we seek to follow more enduring moral considerations. It is only in the radical situations in which even moral reasons, along with social and legal reasons, do not have any grip on us that we cease to be responsible human beings in the Nagelian sense. The criminal law should seek to take this fact into account as much as it legitimately can, and refrain from conceding too easily that emergencies can make us less human. It should recognise that we are morally justified when we infringe its rules but respond fittingly to undefeated reasons. It should also recognise that we are excused when we fail to do so but nevertheless meet the moral standards of skill and virtue applicable to rational agents in relevantly similar predicaments. Only when we are genuinely non-responsible for what we do should the criminal law treat us as such.

${ }^{100}$ Wilson (2004, p. 387). 